\section{LAS PERIFERIAS INTERIORES DE LIMA: LOCALIZACIÓN E IDENTIFICACIÓN DE LOS BARRIOS FOCOS DE VULNERABILIDAD. EL CASO DE SAN COSME ${ }^{1}$}

Paula Kapstein López ${ }^{2}$, Edith Aranda Dioses ${ }^{3}$

\section{Resumen}

Se ha identificado un sistema de periferias interiores en el centro de Lima, el cual integra una serie de antiguas barriadas que conforman una entidad urbana con sus propias características y problemas. Estas barriadas formaban parte de la periferia norte de Lima hasta la década de los años cincuenta, apoyándose en el cauce del río Rímac que entonces ejercía de límite entre el Cercado y la incipiente prolongación del trazado urbano hacia el Norte.

El objetivo de la investigación que el presente artículo recoge se centra en delimitar el sistema de periferias interiores e identificar los barrios que actúan como focos de vulnerabilidad dentro del sistema.

\section{INNER PERIPHERIES OF LIMA: LOCATION AND IDENTIFICATION OF VULNERABILITY- GENERATING NEIGHBORHOODS. THE CASE OF SAN COSME ${ }^{1}$}

Paula Kapstein Lopez ${ }^{2}$ and Edith ArandaDioses ${ }^{3}$

\section{Abstract}

A system of inner peripheries has been identified in downtown Lima, comprising a series of old slums that makes up an urban entity with its own characteristics and problems.These slumswere part of the northern periphery of Lima until the 1950 s and extended along the course of the Rimac River, the then-border between the district of Lima and the emerging northern extension of the urban area.

The objective of this paper is to demarcate the system of inner peripheries and identify the neighborhoods that act as focal points of vulnerability within the system. 
La metodología desarrolla un trabajo de análisis cartográfico enfocado en el crecimiento de Lima en el periodo dado entre 1940 y 1981, seguido de un estudio de las condiciones urbanas y sociales de los barrios focos de vulnerabilidad. En este texto se presenta el caso de San Cosme, una de las barriadas paradigmáticas de Lima, tanto por su antigüedad como por sus características geomorfológicas y urbanas. Los resultados se concentran en fundamentar la necesidad de generar un Plan Director de Estrategias de Rehabilitación para las periferias interiores de Lima.

\section{PALABRAS CLAVE: SISTEMA DE PERIFERIAS INTERIORES, BARRIO FOCO DE VULNERABILIDAD, ANÁLISIS CARTOGRÁFICO DEL CRECIMIENTO URBANO, LIMA.}

Fecha de recepción: 13.01.14

Fecha de aceptación: 29.08.14

1 El presente artículo expone un resumen de la investigación realizada en la Facultad de Arquitectura, Urbanismo y Artes de la Universidad Nacional de Ingeniería de Lima, Perú; la cual se realizó gracias a una subvención del Ministerio de Asuntos Exteriores y de Cooperación de España junto a la Agencia Española de Cooperación Internacional (AECID), entre octubre de 2011 y junio de 2013.

2 Chile. Arquitecta Universidad de Valparaíso, Dra. en Urbanismo Universidad Politécnica de Madrid. Académica Escuela de Arquitectura Universidad Católica del Norte. Correo electrónico: pkapstein@ucn.cl

3 Perú. Socióloga Pontificia Universidad Católica del Perú, Magister Pontificia Universidad Católica del Perú. Profesora principal Universidad Nacional de Ingeniería Correo electrónico: etarad@gmail.com
The methodology used by this research is based both on a cartographic analysis of the growth experienced by Lima from 1940 to 1981 and the study of the urban and social conditions of neighborhoods that act as focal points of vulnerability. This research describes the case of San Cosme, which by reasons of its age and its geomorphological and urban characteristics is one of the paradigmatic slums of Lima. The findings of this paper support the need to generate a Master Plan on Rehabilitation Strategies aimed at the inner peripheries of Lima.

\section{KEYWORDS: SYSTEM OF INNER PERIPHERIES, VULNERABILITY-GENERATING NEIGHBORHOOD, CARTOGRAPHIC ANALYSIS OF URBAN GROWTH, LIMA.}

Received: 13.01.14

Accepted: 29.08.14

1 This paper is part of a research conducted at the Faculty of $\mathrm{Ar}$ chitecture, Urban Planning and Arts of the National University of Engineering, Lima, Peru, from October, 2011 to June, 2013. This research was funded by the Ministry of Foreign Affairs and Cooperation of Spain along the Spanish Agency of International Cooperation (AECID).

2 Chile. Architect, University of Valparaiso.PhD in Urbanism, Technical University of Madrid. Professor, School of Architecture, Northern Catholic University. Email: pkapstein@ucn.cl

3 Peru. Sociologist, Pontifical Catholic University of Peru. MSc, Pontifical Catholic University of Peru. Principal professor at National University of Engineering. Email: etarad@gmail.com 


\section{Introducción}

Durante el siglo XX la ciudad de Lima creció intensamente. Según Matos $\mathrm{Mar}^{4}$ el momento en que comenzó este rápido aumento poblacional se remonta al año 1930. Fue entonces cuando se iniciaron las migraciones hacia Lima, dadas principalmente desde distintos pueblos de Los Andes debido a los grandes niveles de pobreza que éstos tenían.

Las principales características de este crecimiento explosivo son su alta informalidad (en la vivienda y en relación a los mercados de urbanizadores clandestinos formados alrededor de ella) y la configuración de una metrópoli de nueve millones de habitantes que concentra a un tercio de la población peruana y que se compone de barreras de diverso tipo que la fragmentan a un nivel urbano pero también en lo social.

El rápido aumento de tamaño experimentado por la ciudad de Lima se produce entre 1940 y 1981 y no se acompaña de instrumentos de planificación efectivos, generando una degradación de sus espacios centrales, los que quedaron en una situación de alta vulnerabilidad: víctimas de la congestión vehicular, del abandono de sus residentes y de la tugurización de los inmuebles. A partir de esta observación y aplicando una metodología gráfica basada en la detección de límites (tanto internos

4 Matos Mar, 2004.

\section{Introduction}

Lima experienced intense growth over the course of the 20th century. According to Matos Mar ${ }^{4}$, this rapid expansion of the population dates back to the 1930s. It was during that period that people began to migrate to Lima, mainly from highly impoverished Andean towns.

The main characteristics of this explosive growth are informality (in terms of housing and the presence of irregular urbanization in the vicinity) and the configuration of a metropolis of nine million inhabitants that concentrates a third of the total Peruvian population which is composed of diverse barriers that generate urban and social fragmentation.

The rapid growth experienced by the city of Lima between 1940 and 1981 was not accompanied by effective planning instruments. This brought about the decline of central spaces, which became highly vulnerable due to: traffic congestion, abandonment on the part of the city and the degradation of housing. From this observation, and the application of methodology based on a graphic detection of borders (both internal and peripheral), this enabled the identification of

4 Matos Mar, 2004. 
como periféricos) se pudo localizar un sistema de periferias interiores ${ }^{5}$. Es decir, durante el crecimiento explosivo de la ciudad ciertas zonas periféricas antiguas pasaron a quedar en una posición interna y céntrica.

\section{Marco teórico}

Se recoge como base teórica de la presente investigación la tesis doctoral "La Periferia Interior: un problema de vulnerabilidad no resuelto por el planeamiento urbano en Chile"6; abordándose ahora algunos de los conceptos que aquella investigación definía con una nueva significación dada por la complejidad y magnitud que presenta la ciudad de Lima.

\section{HIPÓTESIS Y OBJETIVOS}

A continuación se presentan las principales hipótesis que sustentan la investigación:

- Las periferias interiores de Lima configuran un área de gran tamaño con relaciones entre los barrios vulnerables que la integran. Por esto se puede suponer que este conjunto de periferias interiores conforma un sistema urbano;

Kapstein, 2010.

Kapstein, 2009.

22

revista invi № 82 / Noviembre 2014 / Volumen № 29: 19-62 a system of inner peripheries. ${ }^{5}$ That is to say, during the explosive growth of the city certain old peripheral zones ended up located in the inner and central part of the city.

\section{Theoretical framework}

This research is based on the dissertation "The Inner Periphery. A Vulnerability Issue that has not been resolved by Chilean Urban Planning" and addresses some concepts that have taken on a new meaning as the result of the complexity and volume of the city of Lima.

\section{HYPOTHESES AND OBJECTIVES}

The hypotheses underlying this research are described as follows:

- The inner peripheries of Lima comprise a large area with many connections between the vulnerable neighborhoods that compose this unit. For this reason it can be assumed that this group of inner peripheries make up an urban system;

- The inner peripheries of Lima emerge as the result of massive migrations, mainly

5 Kapstein, 2010.

6 Kapstein, 2009 
- Las periferias interiores de Lima surgen como consecuencia de migraciones masivas a la ciudad, provenientes la mayor parte de ellas de poblados rurales andinos. De este modo, las periferias interiores constituyen la estructura física que permite el traslado de lo rural a lo urbano, es decir, estos espacios son altamente precarios y carentes de orden pero han sido capaces de recoger la variedad de modos de vida rural;

- Hay dos hechos que determinan el carácter del sistema de periferias interiores en Lima; por un lado, los barrios vulnerables que integran dicho sistema tienen unas altas tasas de crecimiento poblacional en el periodo dado entre los años 1940 y 1981; y por otra parte, la densidad de la vivienda aumenta en estos barrios vulnerables a una velocidad comparable a las tasas de crecimiento poblacional.

Para verificar las anteriores hipótesis se plantean los siguientes objetivos:

- Identificar la aparición de este sistema de áreas vulnerables interiores con unas etapas de crecimiento urbano y de formación de la unidad metropolitana de Lima.

- Localizar el sistema de periferias interiores y delimitarlo, reconociendo los barrios que constituyen los focos de vulnerabilidad del sistema. from Andean rural towns. In this way, inner peripheries become the physical structure that enables the transition from the rural environment to the urban environment; in other words, these are poor and disorganized spaces that have been able to absorb the rural way of life;

- There are two facts that define the nature of the system of inner peripheries in Lima; on the one hand, the vulnerable neighborhoods that are part of this system show high rates of population growth during the 1940-1981 period; on the other hand, the housing density of these vulnerable neighborhoods is increasing at a speed comparable to that of population growth rates.

In order to verify these hypotheses this research pursues the following objectives:

- Identify the emergence of a system of inner vulnerable areas with stages of urban growth and the development of the metropolitan area of Lima.

- Locate and demarcate the system of inner peripheries; identify then eighborhoods that act as focal points of vulnerability. 


\section{SOBRE EL PROCESO DE URBANIZACIÓN PERUANO}

En América Latina el proceso de crecimiento urbano se ha visto fuertemente influenciado por las migraciones desde las zonas rurales a las ciudades (dadas desde las primeras décadas del siglo XX hasta inicios de la década de los noventa en muchos casos), lo que ha generado altas concentraciones urbanas.

El proceso de urbanización peruano grafica, de un modo peculiar, el devenir latinoamericano. La gran influencia de la presencia de Los Andes en medio del territorio se evidencia en el lento desarrollo agrícola del país y en la falta de accesibilidad dada entre los poblados serranos, y entre ellos y el resto de ciudades situadas en la costa, todo lo cual incide en el retraso del proceso de urbanización peruano con respecto a otros países de Latinoamérica.

Por otro lado, con respecto al estado de la cuestión de este estudio, se considera el periodo dado entre 1940 y 2007. El año 1940 corresponde al momento en que se intensifican las migraciones hacia Lima, quedando dicho aumento poblacional registrado en el censo de aquel año; y el año 2007 corresponde al último año del censo poblacional realizado por el Instituto Nacional de Estadística e Informática de Perú (INEI).

\section{THE URBANIZATION PROCESS IN PERU}

In Latin America the urban growth process has been strongly influenced by migration from rural zones (since the first decades of the 20th century until the 1990s), which has resulted in high urban concentrations.

The process of Peruvian urbanization shows, in a particular way, the Latin American situation. The strong influence of the Andes on the territory is in evidence by the slow agricultural development of the country and the lack of access of the mountain people to coastal areas; this has resulted in the slow urbanization process of Peru in comparison to other Latin American countries.

On the other hand, and for purposes of discussion, this research analyzed the 1940-2007 period. The year 1940 marked theintensificationof migration flows to Lima and the subsequent population growth, which was recorded in the census conducted that year. Likewise, the last population census, coordinated by the National Statistical Office (INEI), was conducted in 2007.

From 1940 to 20077, the relationship between rural and urban population was reversed. In

7 This paper analyzes the 1940-1981 period, which related to the origin and consolidation of the inner peripheries of Lima. This time span includes three inter-census stages. 
Desde 1940 al año $2007^{7}$, la relación entre la población rural y urbana del Perú se ha invertido: de un 65\% de población rural frente a un 35\% de población urbana en 1940 , a un $24 \%$ de población rural frente a un $76 \%$ de población urbana en 2007 (véase tabla 1 de distribución de población entre los censos de 1940 y 2007). Como puede apreciarse en dicha tabla, en el Censo del año 1961 la población del Perú alcanzó un reparto equilibrado entre lo rural y lo urbano, para invertirse la tendencia ya en el censo de 1972, cuando la población comenzó a ser mayoritariamente urbana. Esta observación se verifica analizando los datos que se presentan en la tabla 2, donde se aprecia que en el periodo dado entre 1961 y 1972 la tasa de crecimiento promedio anual de la población urbana fue de un 5,1\%, la más alta de las últimas décadas.

Entre los años 1940 y 2007 la población urbana del departamento de Lima y de la provincia constitucional del Callao se multiplicó por trece: de 711.441 a 9.152 .700 habitantes $^{8}$; y, en cuanto a su extensión, la ciudad pasó de ser un núcleo relacionado con otros poblados como Callao y Chorrillos a constituir un área metropolitana de $266.467 \mathrm{Ha}$, multiplicando en este periodo su superficie por cuarenta y tres. Estos datos permiten comprobar

7 En este trabajo el periodo que se estudia en relación con el origen y consolidación de las periferias interiores en Lima va de 1940 a 1981. Este periodo incluye tres etapas intercensales.

8 INEI, 2008.
1940, 65 percent of the total population lived in rural areas and the remaining 35 percent lived in urban areas. These figures changed in 2007, with 26 percent of the population living in rural areas and 76 percent living in urban areas. According to 1961 Census data, the total population of Peru was equally distributed in rural and urban areas, as shown in tabla 1. However, such a trend began to de reversed in 1972, when most of the population became urban. This observation can be verified by analyzing the information provided by table 2, which shows that the annual growth rate of urban population was 5.1 percent, the highest in latest decades (see tables 1 and 2).

From 1940 to 2007, the urban population of the Lima department and the constitutional province of Callao rose 13 times: from 711,441 to 9,152,7008 inhabitants. As for its extension, the city went from being a conurbation connected to other towns such as Callao and Chorrillos to a metropolitan area covering 266,467 ha, thereby increasing its surface 43 times. The information provided reveals an obvious fact: the metropolitan unit of Lima and El Callao grewaccording to extensive and diffuse patterns, thus becoming

8 INEI, 2008.

revista invi № 82 / November 2014 / Volume № 29: 19-62 25 
una realidad que se aprecia a simple vista al recorrer la unidad metropolitana de Lima y El Callao: la ciudad presenta un crecimiento en extensión, difuso e insostenible en lo medioambiental pero también en cuanto a su estructura urbana.

Los factores que sustentaron este crecimiento explosivo y difuso pueden resumirse en lo siguiente: emplazamientos apropiados para un crecimiento informal, un clima benigno y una legislación de suelos que facilitó el acceso a tierras no utilizadas.

Con respecto a la legislación estatal, según Driant ${ }^{9}$, históricamente ésta ha reforzado los fundamentos físicos de la estratificación residencial limeña, contribuyendo ampliamente al crecimiento expansivo de la ciudad. El poder colonial estableció una legislación mediante la cual las tierras no trabajadas regresaban al Estado y después de casi cinco siglos este principio sigue vigente. Además, según Riofrío ${ }^{10}$, el Estado peruano no desarrolló una política de vivienda adecuada para los sectores populares durante el siglo XX; la solución a la que se optó consistió en dar libertad para que estos sectores ocuparan terrenos y construyeran barriadas, mientras los intereses privados no se viesen afectados.

En cuanto a la desigualdad referida al tamaño y a la población de Lima en comparación con el resto de ciudades peruanas, se trata de una cuestión que

9 Driant, 1991

10 Riofrío, 1991 unsustainable at environmental and urban level.

The factors that supported this explosive and diffuse growth can be summarized as follows: sites that favored informal growth, a good environment and a land regulation that facilitated access to vacant plots.

Driant $^{9}$ points out that, historically, State legislation has reinforced the physical foundations of residential stratification in Lima, thereby contributing to the growth of the city. Colonial power established legislation that ensured the return of unused lands back to the State; today, after five centuries, such an order still remains in force. Likewise, according to Riofrio ${ }^{10}$, the Peruvian State did not develop any proper housing policy aimed at the poor people during the XX century; the solution chosen was giving this group of people the freedom to occupy lands and build slums so long as private interests were not affected.

The inequality referred to the size and population of Lima in comparison to the rest of Peruvian cities is an issue derived from the predominant economic position attained by this city during

9 Driant, 1991

10 Riofrio, 1991 
TABLA 1. DISTRIBUCIÓN DE POBLACIÓN URBANA Y RURAL DEL PERÚ EN AÑOS CENSALES DESDE 1940 A 2007

\begin{tabular}{lrrrrrr} 
& \multicolumn{1}{c}{1940} & \multicolumn{1}{c}{1961} & \multicolumn{1}{c}{1972} & \multicolumn{1}{c}{1981} & \multicolumn{1}{c}{1993} & 2007 \\
\hline Población censada & 6.207 .967 & 9.906 .746 & 13.538 .208 & 17.005 .210 & 22.048 .356 & 27.412 .157 \\
\hline Población urbana & 2.197 .133 & 4.698 .178 & 8.058 .495 & 11.091 .923 & 15.458 .599 & 20.810 .288 \\
\hline Población rural & 4.010 .834 & 5.208 .568 & 5.479 .713 & 5.913 .287 & 6.589 .757 & 6.601 .869 \\
\hline \% urbana & 35,39 & 47,42 & 59,52 & 65,23 & 70,11 & 75,92 \\
\hline \% rural & 64,61 & 52,58 & 40,48 & 34,77 & 29,89 & 24,08 \\
\hline
\end{tabular}

Fuente: INEI, 2008

TABLE 1.DISTRIBUTION OF THE URBAN AND RURAL POPULATION OF PERU IN CENSUS YEARS FROM 1940 TO 2007

\begin{tabular}{lrrrrrr} 
& \multicolumn{1}{c}{1940} & \multicolumn{1}{c}{1961} & \multicolumn{1}{c}{1972} & \multicolumn{1}{c}{1981} & \multicolumn{1}{c}{1993} & \multicolumn{1}{c}{2007} \\
Census Population & $6,207,967$ & $9,906,746$ & $13,538,208$ & $17,005,210$ & $22,048,356$ & $27,412,157$ \\
\hline Urban Population & $2,197,133$ & $4,698,178$ & $8,058,495$ & $11,091,923$ & $15,458,599$ & $20,810,288$ \\
\hline Rural Population & $4,010,834$ & $5,208,568$ & $5,479,713$ & $5,913,287$ & $6,589,757$ & $6,601,869$ \\
\hline Urban \% & 35.39 & 47.42 & 59.52 & 65.23 & 70.11 & 75.92 \\
\hline Rural \% & 64.61 & 52.58 & 40.48 & 34.77 & 29.89 & 24.08 \\
\hline
\end{tabular}

Source: INEI, 2008

TABLA 2. TASAS DE CRECIMIENTO PROMEDIO ANUAL DE LA POBLACIÓN CENSADA SEgÚN ÁREA DE RESIDENCIA

\begin{tabular}{llllll} 
Área residencia & $1940-1961$ & $1961-1972$ & $1972-1981$ & $1981-1993$ & $1993-2007$ \\
Total & 1,9 & 2,8 & 2,6 & 2,0 & 1,6 \\
\hline Urbana & 3,7 & 5,1 & 3,6 & 2,8 & 2,1 \\
\hline Rural & 1,2 & 0,5 & 0,8 & 0,9 & 0,01 \\
\hline
\end{tabular}

Fuente: INEI, 2008.

TABLE 2.ANNUAL GROWTH RATES OF CENSUS POPULATION ACCORDING TO THEIR AREAS OF RESIDENCE

\begin{tabular}{llllll} 
Area of Residence & $1940-1961$ & $1961-1972$ & $1972-1981$ & $1981-1993$ & $1993-2007$ \\
\hline Total & 1.9 & 2.8 & 2.6 & 2.0 & 1.6 \\
\hline Urban & 3.7 & 5.1 & 3.6 & 2.8 & 2.1 \\
\hline Rural & 1.2 & 0.5 & 0.8 & 0.9 & 0.01 \\
\hline
\end{tabular}

Source: INEI, 2008 
responde al gran peso alcanzado por Lima en la economía nacional durante la segunda mitad del siglo XX. Según Gonzales de Olarte ${ }^{11}$ el intenso flujo migratorio hacia ella es el aspecto más visible de su crecimiento, en cambio, lo que resulta menos visible es la movilidad de recursos y de capitales del resto de regiones y desde el extranjero hacia Lima, lo cual ha contribuido a reforzar un proceso de acumulación de capital relativamente mayor al del resto de regiones.

\section{PERIFERIA INTERIOR Y BARRIADAS EN LIMA}

El concepto de Periferia Interior al que se hace referencia en este trabajo se basa en la definición que aporta Kapstein ${ }^{12}$ :

Es el sistema formado por aquellos espacios urbanos degradados que se ubican en el centro de una ciudad, correspondientes a zonas de una antigua periferia que quedó congelada en el tiempo: el crecimiento de la trama urbana atravesó esta zona en su recorrido, olvidando su desarrollo y atrapándola en medio de la ciudad, lo que le asigna la condición de límite entre áreas de distinto uso y categoría.

A partir de la anterior definición se hace necesario recordar la visión sistémica con la que se consideran las periferias interiores en este trabajo. En este sentido, el concepto de intersticio aportado

11 Gonzales de Olarte, 1992

12 Kapstein, 2009, p.96. the second half of the 20th century. According to Gonzales de Olarte ${ }^{11}$, the intense migratory flow is the most visible aspect of its growth; however, a less visible feature is the mobilization of resources and capital from the rest of the regions - and from abroad - to the city of Lima. The latter has contributed to reinforce a process of accumulation of capitalthat is relatively greater than that of the rest of the regions.

\section{INNER PERIPHERIES AND SLUMS IN LIMA}

The concept of Inner Periphery discussed by this paper is based on the definition used by Kapstein ${ }^{12}$ :

It is the system composed of those deteriorated urban spaces located in the downtown of the city, which correspond to zones of an old periphery that remained frozen in time: the growth of the urban fabric passed through this area, neglecting its development and enclosing it within the city and as a result this space became the border between different spaces used for different purposes.

This definition implies recalling the systemic approach used to address the inner peripheries described in this paper. In this respect the concept

11 Gonzales de Olarte, 1992

12 Kapstein, 2009, p.96 
por Hannerz ${ }^{13}$ se relaciona con el de Periferia Interior, ya que ésta se configura a partir de aquellos intersticios urbanos que pertenecen a espacios situados entre un lugar y otro ${ }^{14}$. La capacidad de reunir barrios vulnerables, industrias en desuso, áreas abandonadas, terrenos eriazos y espacios naturales contaminados o degradados, proviene de esta condición intersticial que tiene el sistema de periferias interiores.

Por otro lado, el concepto de barriada alude a la organización de pobladores carentes de vivienda que ocupan un terreno y actúan colectivamente para autorresolver sus problemas de habilitación urbana y de organización social ${ }^{15}$. Dicho concepto del hábitat popular peruano, según Matos $^{16}$ nace en Lima entre 1945 y 1949, periodo que corresponde a la intensificación de migraciones andinas hacia las ciudades costeras. En dicho intervalo de tiempo, Asimismo, comenzó la invasión organizada de terrenos.

La elección del periodo de estudio se refiere a la formación de periferias interiores en Lima. Dicho proceso se dio entre 1940 y 1981, ya que en dicho periodo el crecimiento de la ciudad fue más acelerado que durante el resto del siglo XX (ver tabla de la figura 1), formándose la unidad metropolitana

\footnotetext{
13 Hannerz, 1993

14 Kapstein, 2009.

15 Matos Mar, 2012.

16 Íbíd.
}

of interstice provided by Hannerz ${ }^{13}$ relates to Inner Peripheries, due to the latter being composed of urban interstices belonging to spaces located between one place and another. ${ }^{14}$ The capacity to gather vulnerable neighborhoods, disused industries, abandoned spaces, deserted lands and polluted or deteriorated lands derives from the interstitial condition that characterizes the system of inner peripheries.

On the other hand, the concept of slum refers to the organization of dwellers in need of housing who occupy a portion of land and perform collective actions to self-resolve their urban-related and social organization issues (Matos Mar ${ }^{15}$ ). As Matos $^{16}$ suggests, thelow-income housing concept emerged in Lima between 1945 and 1949. Such a span of time coincides with the increase in the migration flows from the Andean regions to the coastal cities. Likewise, this period marked the beginning of the organized occupation of land.

This period was chosen as it refers to the emergence of the inner peripheries of Lima. A process which took place between 1940 and 1981 - a period in which the growth of the city reached its peakand led to the creation of the current metropolitan

\footnotetext{
13 Hannerz, 1980

14 Kapstein, 2009.

15 Matos Mar, 2012.

16 Ibíd.
} 
que hoy conocemos, salvo algunas diferencias de tamaño y población dadas por nuevas invasiones en el norte y en el sur de la ciudad, posteriores al año 1981.

El sistema de periferias interiores de Lima se compone de barrios vulnerables relacionados entre sí por límites que asignan una continuidad entre estos barrios ${ }^{17}$. Dichos barrios corresponden a barriadas históricas que pueden estar consolidadas o a medio consolidar, pero que tienen en común su posición céntrica en la ciudad y su cercanía al cauce del río Rímac.

\section{Metodología}

\section{PROCESO METODOLÓGICO}

La metodología seguida en la investigación tuvo dos fases; por una parte, se realizó la delimitación del sistema de periferias interiores en una secuencia de planos referidos a los años 1940, 1950, 1961, 1972 y 1981, ya que dichos años corresponden al periodo de mayor crecimiento poblacional de Lima y además están censados por el INEI. Para hacer posible el análisis comparativo entre estos planos, fue necesario representarlos sobre una misma base cartográfica, para lo cual se consideró el plano de

17 Históricamente estos mismos límites crearon discontinuidades en el trazado urbano de Lima entre el centro fundacional y su expansión hacia el norte. area except for a few differences in size and population resulting from new encroachments in the northern and southern areas of the city that occurred after 1981 (see figure 1).

The system of inner peripheries of Lima comprises vulnerable neighborhoods related to each other by borders that ensure continuity between them. ${ }^{17}$ These neighborhoods are historical slums that may be consolidated or semi-consolidated; however, they share their central location within the city and their closeness to the Rimac River.

\section{Methodology}

\section{METHODOLOGICAL PROCESS}

The methodology used by this research was divided into two phases. On the one hand, the system of inner peripheries was demarcated according to maps for the census years of 1940, 1950, 1961, 1972 and 1981 - a time span in which the population growth of the city reached its peak. The comparative analysis among these maps was conducted through the use of a single cartographic base; for this purpose, the map of Lima (2012)

17 Historically, these borders generated discontinuities within the urban layout of Lima between the historical district and its expansion towards the north. 
Lima del año 2012. A partir de este se dibujaron secuencialmente todos los planos de evolución del trazado urbano hasta el plano más antiguo, el de $1940(\mathrm{IGN})^{18}$. Los antecedentes gráficos que permitieron definir el perímetro de lo urbano en cada plano son variados; sin embargo, se debe citar de forma especial el trabajo supervisado por el Arq. Luis Sipión (INEI-INADUR) ${ }^{19}$.

Una vez que los planos estuvieron dibujados, en cada uno de ellos se trazaron los límites internos y los límites periféricos, buscando definir no sólo la delimitación del sistema de periferias interiores si no su estructura actual, dada por la existencia de barrios que actúan como focos de vulnerabilidad dentro del sistema.

La identificación de los barrios focos de vulnerabilidad corresponde a la segunda parte de la metodología y se realizó mediante un trabajo de campo que incluyó visitas a terreno y encuestas a dirigentes poblacionales y a los vecinos de la mayoría de las barriadas que integran el sistema. Al mismo tiempo, se estudiaron los antecedentes referidos al origen y formación de cada una de dichas barriadas. Este trabajo permitió definir lo que es un barrio foco de vulnerabilidad para, a continuación,

18 Este trabajo se considera uno de los aportes gráficos de esta investigación ya que los planos anteriores al año 1972 no estaban digitalizados. La fuente del plano del año 2012 es el Instituto Geográfico Nacional de Perú (IGN).

19 Sipión, 1995. was considered. This map was used to draw, on a sequential basis, the evolution of the urban plan until reaching the oldest map, which takes us back to $1940($ IGN $) .{ }^{18}$ Different graphic sources were used to demarcate the urban perimeter of each map; however, a special mention should be given to the work supervised by Architect Luis Sipion (INEI-INADUR). ${ }^{19}$

Once the maps were completed, the identification of both inner and peripheral borders was pursued. This was carried out not only to demarcate the limits of the system of inner peripheries, but also to define its current structure, which is based on the existence of neighborhoods that act as focal points of vulnerability.

The second part of this methodology corresponds to the identification of these neighborhoods that act as focal points of vulnerability. This was achieved by conducting field visits and interviews to local leaders and neighbors from many slums belonging to this system. Likewise, the origins and emergence of each of these slums were also analyzed. This research provides a definition of a vulnerability-generating neighborhood and

18 This work is a graphic contribution of this research, as there were no digital maps prior to 1972. The source of the 2012 map is the National Geographic Institute (IGN).

19 Sipion, 1995. 
realizar la selección de cuatro de estos barrios incluidos en el sistema. Este artículo presenta uno de ellos, San Cosme. Del análisis de este barrio se extraen observaciones que permiten entender la formación y devenir de otras partes del sistema.

Finalmente, el análisis de las condiciones urbanas y sociales de los barrios incluidos en la zona identificada como sistema de periferias interiores permitió concluir sobre la necesidad de posibilitar una regeneración de la vulnerabilidad en dicha zona, sin dejar de entenderla como parte de una entidad mayor, la Lima metropolitana.

\section{REFLEXIONES METODOLÓGICAS}

La ciudad es un hecho artificial que obedece a actos de acondicionamiento del medio físico y a patrones transmitidos por una técnica (un modo de construir y de asentarse en el territorio) y una cultura (un modo de interpretar el mundo). De aquí que en la ciencia urbana se mezclen diversos aspectos del conocimiento con otros aspectos operacionales relacionados con los métodos de transformación del medio físico y, en definitiva, de la ciudad (como el planeamiento). La anterior dicotomía se refleja también en la presente investigación. En este sentido, este es un trabajo netamente "urbano" pues tanto en el planteamiento inicial como en el análisis de casos se dan ambas ópticas, es decir, la investigación muestra aspectos relacionados con una aproximación cuantitativa de los asuntos que chooses four of these units; this paper particularly focuses on the neighborhood of San Cosme. The analysis of this unit also provides observations on the origin and history of other areas of this system.

Finally, the analysis of the urban and social conditions of the neighborhoods belonging to the system of inner peripheries sheds light on the need to reverse the vulnerability of this area based on the understanding that this space is also part of the metropolitan area of Lima.

\section{METHODOLOGICAL REFLECTIONS}

The city is an artificial construct that reflects the conditioning of the physical environment and patterns transmitted through techniques (construction and settlement methods) and culture (ways of interpreting the world). It is from here that urban science is a discipline which mixes various aspects of knowledge with other operational aspects of processing methods of the physical environment and, ultimately, the city (such as urban planning). Such a dichotomy is outlined in this paper. In this sense, the initial approach of this urban-oriented research and the analysis of cases deal with these two perspectives; in other words, this paper uses a quantitative approach to address the issues discussed herein 
se tratan y, complementariamente, presenta análisis cualitativos que incluyen diversos enfoques.

Esta investigación se plantea con el fin de situar el concepto de vulnerabilidad en el campo de la urbanística, apoyándonos en otros enfoques como lo social o lo físico, pero centrando el proceso metodológico en identificar los problemas de vulnerabilidad en el interior de la ciudad de Lima.

\section{Barrios vulnerables que componen el sistema de periferias interiores}

\section{ANÁLISIS CARTOGRÁFICO Y LOCALIZACIÓN DEL SISTEMA DE PERIFERIAS INTERIORES}

Las periferias interiores corresponden a antiguas zonas periféricas que la ciudad, al ir creciendo, deja incorporadas en su tejido. Esto se pudo verificar estudiando el crecimiento del trazado urbano en planos referidos al siglo XX, entre los cuales cabe resaltarse el plano de 1908 que muestra la configuración de una especie de triángulo territorial que entonces lo constituían Lima y sus balnearios. El Plan Piloto de 1949 también presenta características que ayudan a definir el crecimiento de la ciudad. Estos planos pueden verse en las figuras 1 y 2 . and it offers a complementarily qualitative analysis that includes different approaches.

This research is intended to place the concept of vulnerability withinthe urban development domain. In order to do so we rely on social and physical approaches with the aim of focusing the methodological process on the identification of vulnerability problems within the city of Lima.

\section{Vulnerable neighborhoods comprising the system of inner peripheries}

\section{CARTOGRAPHIC ANALYSIS AND THE LOCATION OF THE SYSTEM OF INNER PERIPHERIES}

Inner peripheries are old peripheral zones that were incorporated within the urban fabric as the result of the expansion of the city. This was verified by analyzing maps dating back to the 20th century which documents a process of increasing urban growth. Chief among these maps is a diagram from 1908 that depicts the configuration of a territorial triangle that comprised Lima and its seaside area. The Pilot Plan of 1949 also shows some characteristics that contributed to define the expansion of the city (see figures 1 and 2). 
FIGURA 1. PLANO DE LIMA DE LAS EMPRESAS ELÉCTRICAS ASOCIADAS, 1908 FIGURE 1. MAP OF LIMA, ASSOCIATED ELECTRIC COMPANIES, 1908

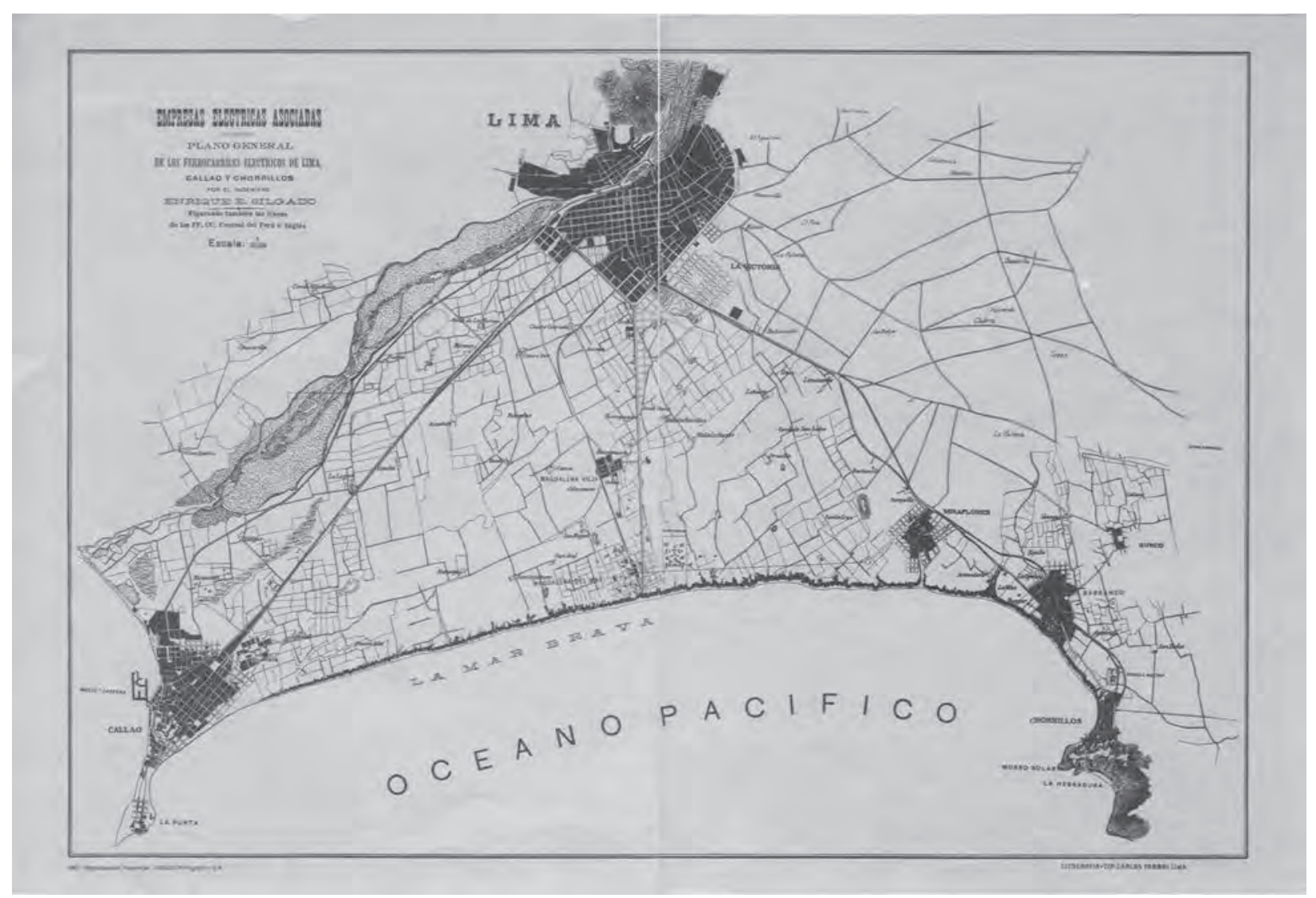

Fuente: "Planos de Lima 1613-1983" de J. Gunther Doering, 1983.

Source: "Maps of Lima 1613-1983", J. Gunther Doering, 1983. 
FIGURA 2. PLAN PILOTO DE LIMA DE 1949

FIGURE 2. PILOT PLAN OF LIMA, 1949

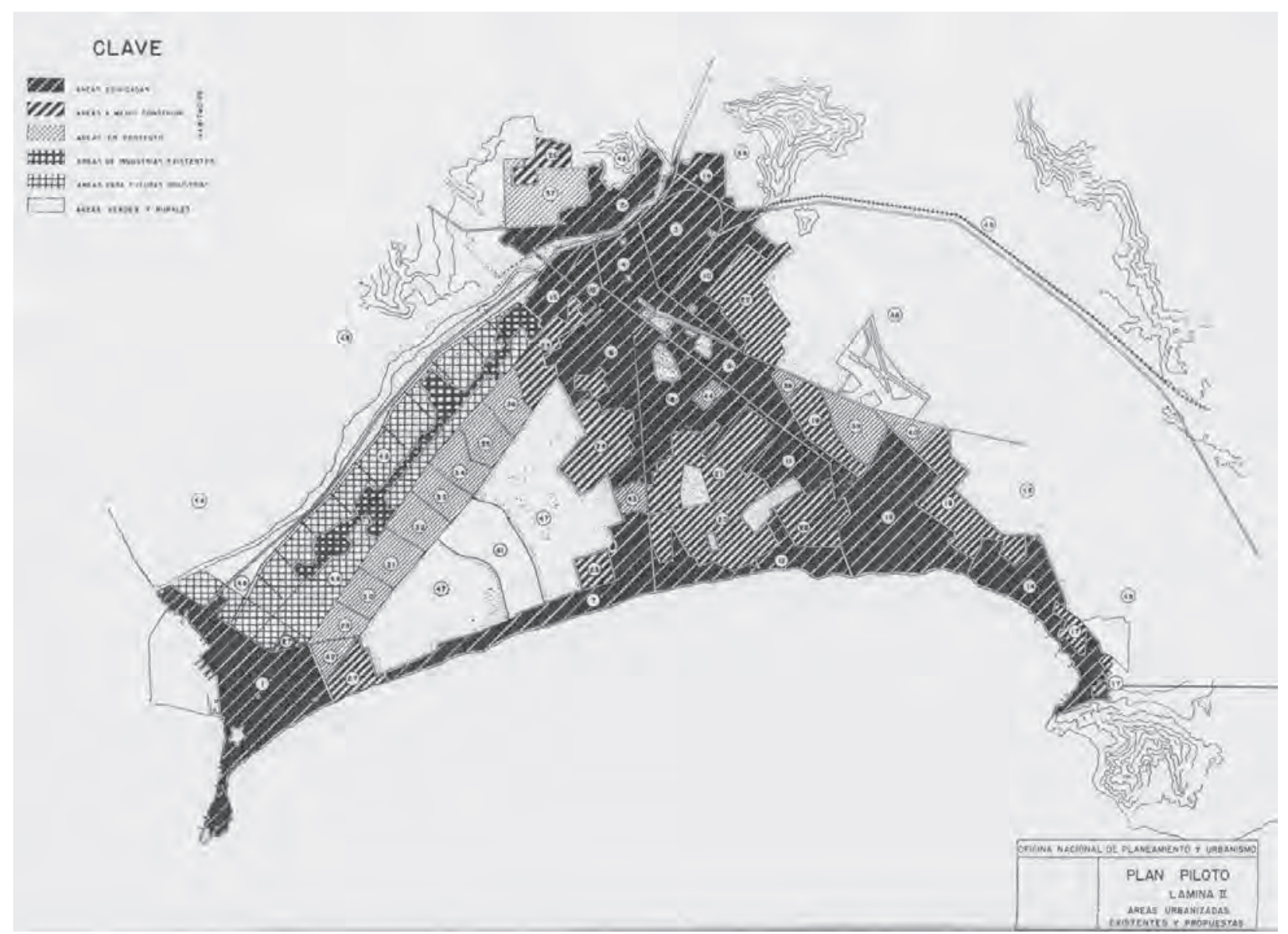

Fuente: Plan Piloto de Lima. Oficina Nacional de Planeamiento y Urbanismo. Res. Suprema No 256 de 12 de septiembre de 1949.

Source: Pilot Plan of Lima. National Office for Land Planning and Urban Development. Supreme Decree n 256, September 12, 1949.

ARTíCULO: Las periferias interiores de Lima: localización e identificación de los barrios focos de vulnerabilidad. El caso de San Cosme / Paula Kapstein López, Edith Aranda Dioses 
En el plano del Plan Piloto del año 1949 quedan reflejadas, además de las áreas edificadas a esa fecha, las áreas en proyección, las áreas a medio construir, las industrias existentes y el área de industrias proyectadas (figura 2). Este Plan fue desarrollado por la Oficina Nacional de Planeamiento y Urbanismo con el fin de precisar los límites de la ciudad y definir las áreas que serían ocupadas por las nuevas unidades de vivienda construidas por el Estado; el plano de la figura 2 resulta de utilidad porque muestra claramente cuáles son las zonas que no se habían edificado en el año 1949. En este plano se aprecia aún sin clasificar gran parte de los terrenos de la zona situada al norte de la bisectriz del triángulo territorial, que queda definida por la avenida Brasil.

Por otro lado, la cercanía del puerto, donde se requería mano de obra no especializada, constituyó otro de los factores que hicieron que las márgenes del río Rímac se convirtiesen en una de las primeras barriadas de la ciudad. Además, dichos suelos resultaban ser de escasa calidad dada su cercanía a la zona industrial, que en el plano del Plan de 1949 ya aparece claramente definida.

\section{LOCALIZACIÓN Y DELIMITACIÓN DEL SISTEMA DE PERIFERIAS INTERIORES}

Se partió localizando un sistema de periferias interiores ubicado en sentido Oeste-Este (desde el mar a los cerros), apoyado por el recorrido del río
Apart from showing the then-built up areas, the Pilot Plan of 1949 also provides information regarding projection areas, half-built areas, industries and the projection of areas for industrial purposes. This Plan, developed by the National Office for Land Planning and Urban Development, was intended to identify the borders of the city and define the areas that would be used by the new housing units built by the State. Figure 2 clearly shows the undeveloped areas by 1949. This map also shows most of the then-unclassified lands belonging to the area north of the bisecting line that runs through the territorial triangle, which corresponds to Brazil Avenue (see figure 2).

On the other hand, the closeness to the harbor - and its need of non-qualified workforce- was another factor that turned the banks of the Rimac River into one of the first slums of the city. In addition, these were poor-quality land plots due to their closeness to the industrial district, which had already been defined in the Pilot Plan of 1949.

\section{LOCATION AND DEMARCATION OF THE SYSTEM OF INNER PERIPHERIES}

Location and Demarcation was achieved throughthe identification of a system of inner peripheries -located within the historic city center - that runswest to east (from the ocean 
Rímac y adyacente al núcleo histórico de la ciudad. Este sistema urbano se configura como una unidad por los elementos que lo componen y le otorgan continuidad (como el río Rímac y algunas vías de circulación) pero, al mismo tiempo, se presenta como un universo altamente fragmentado, compuesto por partes diferenciadas que no quedan articuladas entre sí. En cuanto a la realización de una primera definición del perímetro de la zona, este se ha perfilado siguiendo las calles que marcaban un cambio en la ocupación del suelo. Cuando esto no ha sido posible, se ha identificado el nivel de cotas que definen un cambio en la pendiente, determinando zonas todavía sin ocupar, tal como se ha hecho en la zona del cerro San Cristóbal (ubicado en la zona B en el plano de la figura 3).

El sistema de periferias interiores reconocido puede dividirse en tres grandes zonas. Todas ellas formaron parte de la periferia norte de Lima durante el proceso de expansión de la ciudad dado durante el siglo XX (plano de la figura 3):

- A. La zona oeste adyacente al curso del río Rímac, entre la avenida Elmer Faucett y el puente de la calle Alfonso Ugarte, formada por parte de los distritos de Callao, San Martín de Porres y el Cercado de Lima;

- B. La zona compuesta por parte de los distritos de Rímac y San Juan de Lurigancho ubicados en el lado norte del río; to the highlands), and adjacent to the course of the Rimac River. This urban system emerges as a unit due to the nature of the elements that ensure its continuity (such as the Rimac River and some roads). However, this system is also a highly fragmented universe composed of contrasting areas that are not connected to each other. The first definition of the perimeter of this area was carried out through the identification of the streets that marked a change in land use. In the cases where this was not possible, the different elevation heights of the ground were identified allowing the categorization of unused areas, as in the case of the San Cristobal area (zone B, figure 3).

This system can be divided into three large areas. All of them were part of the northern periphery of Lima during the expansion process experienced by the city over the XX century (see figure 3).

- A. The western area located along the course of the Rimac River, between Elmer Faucett Avenue and the Alfonso Ugarte Street bridge. This zone comprises the districts of Callao, San Martin de Porres and Lima.

- B. The area comprising part of the districts of Rimac and San Juan de Lurigancho, located on the north bank of the river. 
FIGURA 3. IDENTIFICACIÓN DEL SISTEMA DE PERIFERIAS INTERIORES

FIGURE 3. IDENTIFICATION OF THE SYSTEM OF INNER PERIPHERIES

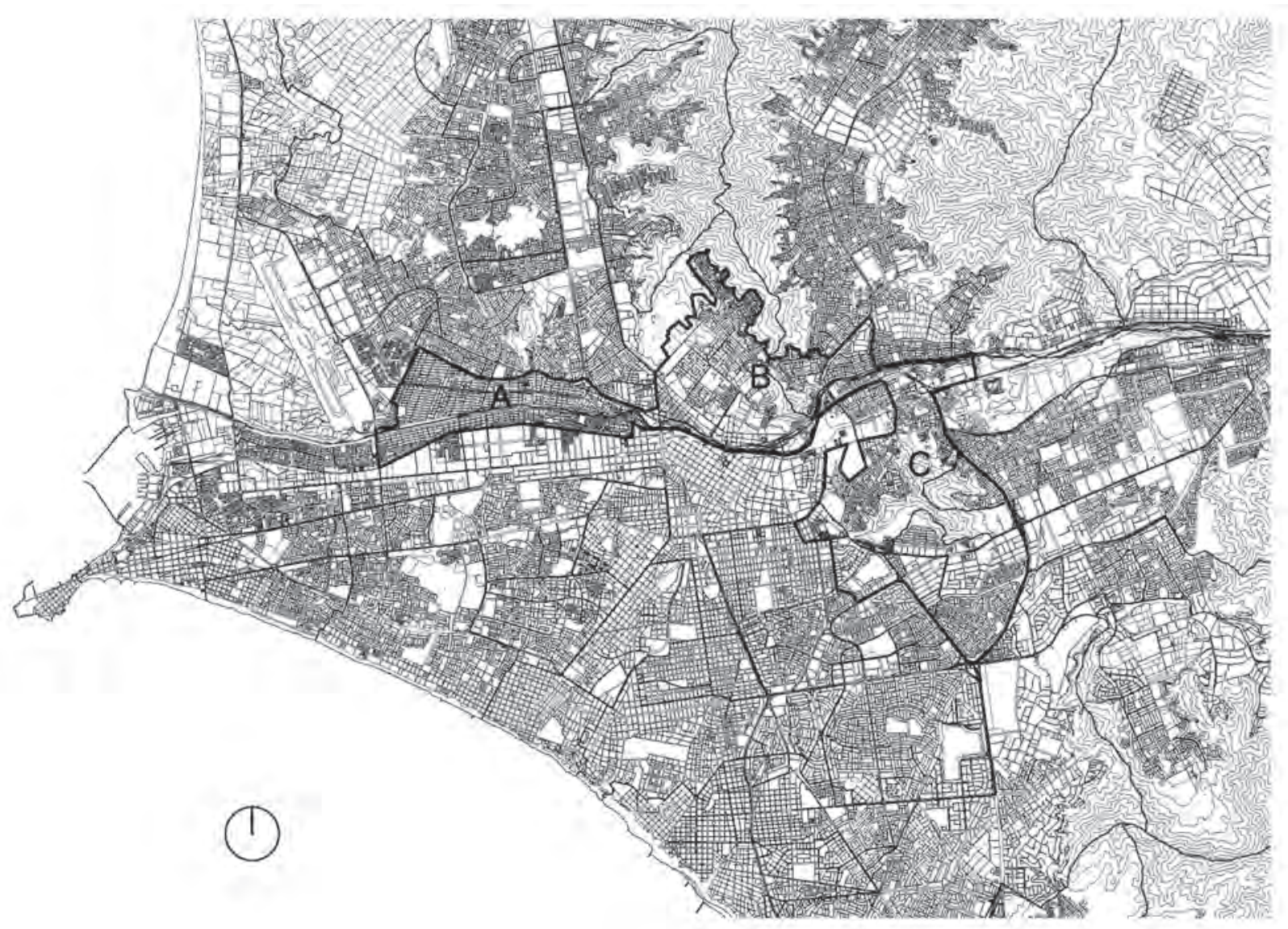

Fuente: Plano de elaboración propia en base al plano de Lima del Instituto Geográfico Nacional, año 2012.

Source: Elaborated by the author based on the map of Lima issued by the National Geographic Institute, 2012. 
- C. La zona sur del río que queda delimitada por el río Rímac, la vía del Evitamiento, parte de la carretera Central, avenida Nicolás Arriola y avenida México hasta Grau. Esta zona es la más amplia e integra la mayor parte del distrito de El Agustino y parte de los de Santa Anita, Ate Vitarte y La Victoria.

La delimitación inicial que muestra el plano de la figura 3, se corrigió posteriormente a través de un estudio cartográfico que tuvo por objeto definir un perímetro para el sistema de periferias interiores de Lima (figura 4: imágenes a, b, c, d y e). El trabajo, básicamente, consistió en representar los límites periféricos (en blanco) y los límites internos de cada año ${ }^{20}$ (en rojo) en cada uno de los planos de los años estudiados (1940, 1950, 1961, 1972 y 1981).

En otro orden de cosas, en el caso de Lima resulta pertinente hablar de sistema de periferias interiores por el tamaño de la unidad metropolitana y por su proceso de crecimiento dado en la conurbación con otros núcleos; de este modo, la definición de un área vulnerable interior pasa por reconocer que esta no se presenta como una zona aislada (como puede ocurrir en las ciudades de menor tamaño y con dinámicas de crecimiento diferentes), sino como un territorio urbano complejo con partes

20 Los límites internos corresponden a antiguos límites periféricos de la ciudad.
- C. The southern area of the river, which is delimited by the Rimac River, the Evitamiento road, part of the Central highway, Nicolas Arriola Avenue, Mexico Avenue and Grau Avenue. This is the largest zone and comprises most of the district of El Agustino and part of the districts of Santa Anita, Ate Vitarte and La Victoria.

The initial demarcation shown by figure 3 was corrected through a cartographic study intended to define the perimeter of the system of inner peripheries of Lima (figure 4:images $a, b, c, d$ and e). Such an exercise consisted in representing the peripheral limits (white) and the inner limits ${ }^{20}$ of each map analyzed (1940, 1950, 1961, 1972 and 1981).

In the case of Lima, it is appropriate to talk about the system of inner peripheries due to the size of the metropolitan unit and the expansion process experienced by such a unit; therefore, the definition of a vulnerable inner area depends onrecognizing that this is not an isolated zone (as in the case of smaller cities with different growth dynamics), but a complex urban territory with clearly differentiated places that are connected to each other, thus forming a system.

20 The inner borders correspond to the former peripheral limits of the city.

revista invi No 82 / November 2014 / Volume № 29: 19-62 
claramente diferenciadas y articuladas entre sí, que forman un sistema.

Finalmente, el sistema de periferias interiores delimitado en Lima es una zona extensa ubicada alrededor del centro histórico de la ciudad. Su superficie es de $2.710 \mathrm{ha}^{21}$ y se compone de nueve distritos $^{22}$ : Callao, Cercado de Lima, San Martín de Porres, Rímac, San Juan de Lurigancho, El Agustino, Ate, Santa Anita y La Victoria (ver plano de la figura 7). La zona delimitada cuenta con una población aproximada de medio millón de habitantes ${ }^{23}$.

A continuación se presentan los cinco primeros planos, de los años 1940, 1950, 1961, 1972 y 1981, que corresponden al periodo de mayor expansión urbana de Lima.

Entre 1940 y 1950 al mismo tiempo que comienza a urbanizarse el interior del que hemos denominado "triángulo territorial", la ciudad se extiende hacia el norte del límite que define el cauce del río Rímac, donde comienzan a aparecer las primeras

21 Superficie medida sobre el plano de Lima del Instituto Geográfico Nacional del año 2012

22 Estos distritos no quedan incorporados en toda su extensión en el sistema de periferias interiores.

23 El sistema de periferias interiores integra zonas de distintos distritos y no está censado. La población se ha estimado verificando en el plano de Lima del año 2012 la superficie de cada distrito contenida en la zona de periferias interiores, deduciéndose un porcentaje referido a esta relación, lo que finalmente arroja una población aproximada de 503.000 habitantes.
Finally, this system of inner peripheries is a vast area located around the historic city center. This system covers 2,710 $\mathrm{ha}^{21}$ and comprises of nine districts ${ }^{22}$, namely, Callao, Cercado de Lima, San Martin de Porres, Rimac, San Juan de Lurigancho, El Agustino, Santa Anita and La Victoria. This delimited area has a population of about half a million inhabitants ${ }^{23}$ (see figure 7).

Below are the first five maps corresponding to 1940, 1950, 1961, 1972 and 1981 - a time span in which the urban growth of the city reached its peak.

From 1940 to 1950 - parallel to the urbanization process within the "territorial triangle"- the city began to expand towards the northern border, which is defined by the Rimac River. This resulted in the emergence of the first slums in the foothills of the city.

21 Surface measured over the map of Lima (2012) prepared by the National Geographic Institute.

22 These districts are not fully incorporated into the system of inner peripheries.

23 The system of inner peripheries comprises zones from different districts and it has not been registered. The map of Lima for the year 2012 was used to estimate the total population of this system, which was calculated through the verification of the surface of each district contained within the zone of inner peripheries. This resulted in a percentage referred to this relation that is translated into a population of approximately 503,000 inhabitants. 
FIGURA 4. DELIMITACIÓN DEL SISTEMA DE PERIFERIAS INTERIORES: LOS LÍMITES PERIFÉRICOS (TRAZADOS EN BLANCO) ADQUIEREN LA CONDICIÓN DE LÍMITES INTERNOS SEGÚN VA CRECIENDO LA CIUDAD FIGURE 4. DEMARCATION OF THE SYSTEM OF INNER PERIPHERIES: THE PERIPHERAL BORDERS (WHITE) BECOME INNER BORDERS (RED) AS THE CITY EXPANDED
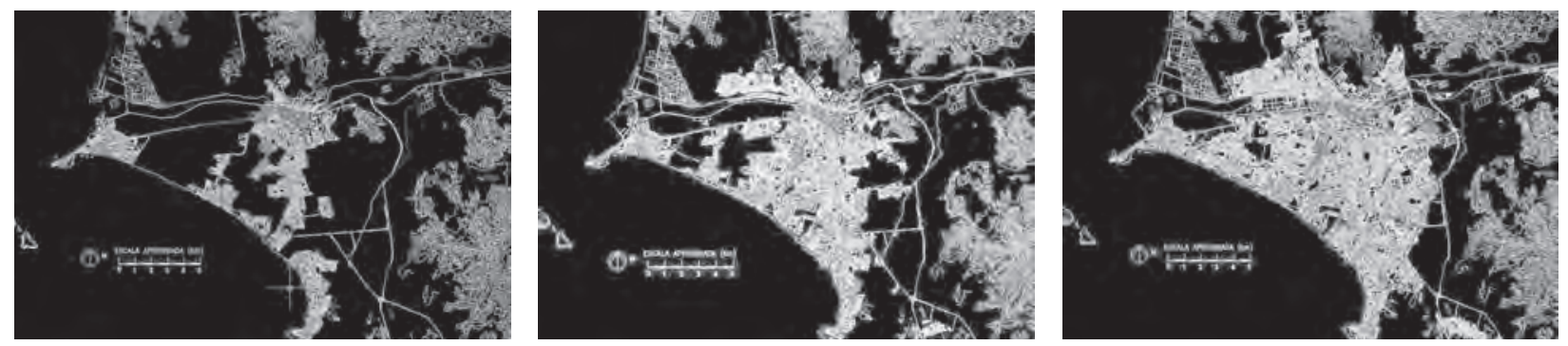

4a Plano de 1940

4b Plano de 1950

4c Plano de 1961.
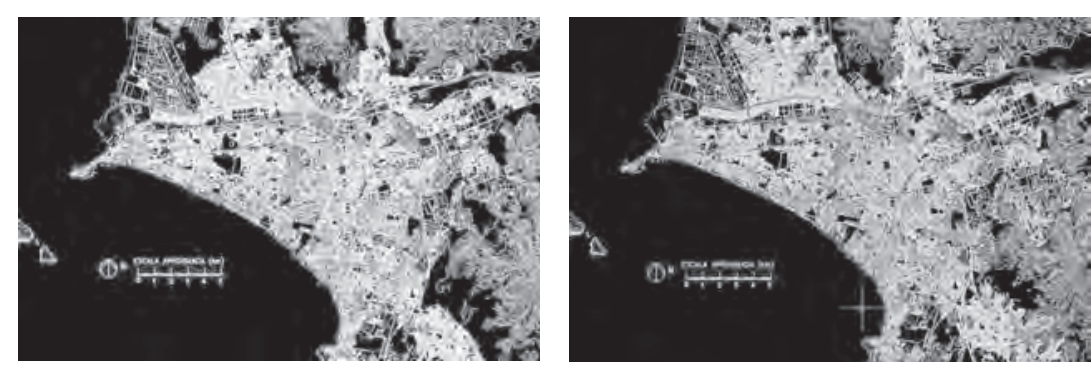

4d Plano de 1972

Fig. 4e Plano de 1981.

Fuente: Elaborado por Paula Kapstein

Source: Elaborated by Paula Kapstein. 
FIGURA 5. DELIMITACIÓN FINAL DEL SISTEMA DE PERIFERIAS INTERIORES DE LIMA FIGURE 5. FINAL DEMARCATION OF THE SYSTEM OF INNER PERIPHERIES OF LIMA

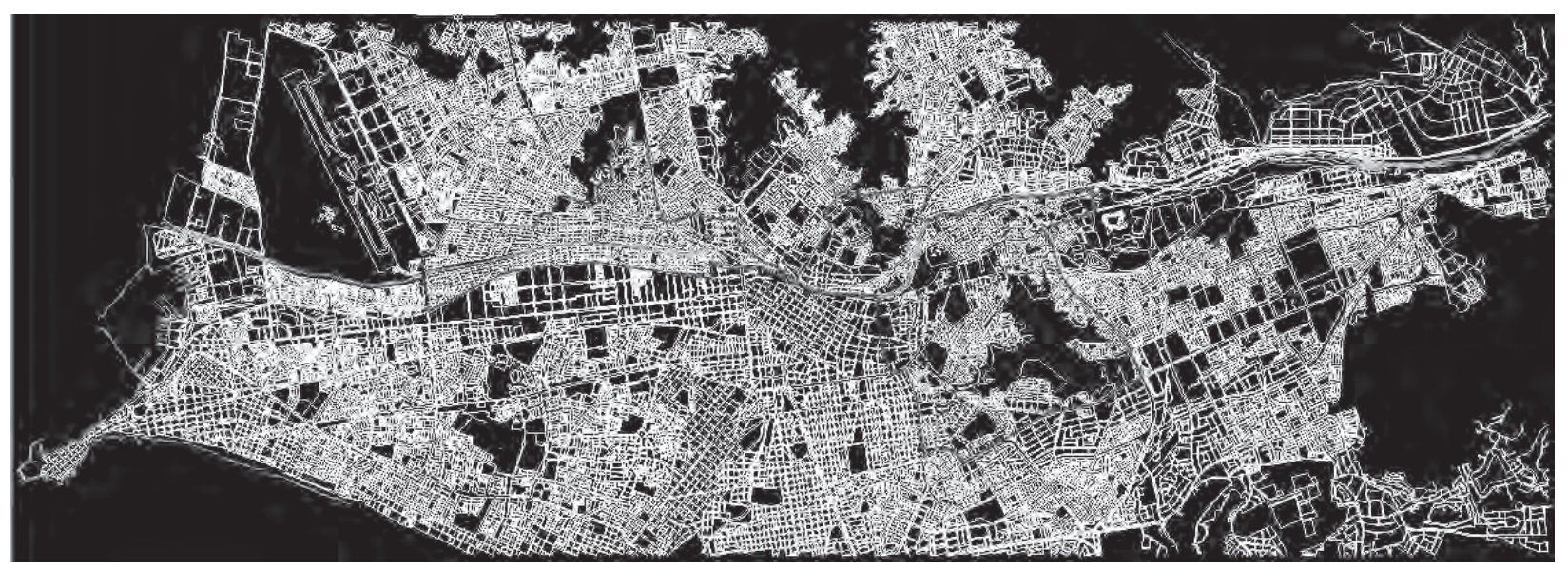

Fuente: Elaboración propia.

Source: Elaborated by the author.

barriadas adyacentes a las estribaciones de los cerros.

En el plano de 1950 aún se aprecian zonas entre El Callao y El Cercado de Lima y en San Miguel sin urbanizarse. Sin embargo, entre 1950 y 1961 estas zonas prácticamente aparecen colmatadas. Asimismo, en el plano de 1961 se aprecia que la ciudad ya se extiende en una mancha continua hacia el norte e incluso algunos límites que eran periféricos en el plano anterior, ahora ocupan una posición interna.
As for the map of 1950, there are still unused zones in the area surrounding El Callao, the District of Lima and San Miguel. However, these areas were almost completely urbanized by 1961 . Likewise the map of 1961 shows an urban sprawl extending northwards from the metropolis. It is also possible to see that some former peripheral borders are now located within the city.

From 1961 to 1972, the city began to expand southwards and the northern area became 
Entre los años 1961 y 1972 la ciudad comienza a extenderse al Sur, y la extensión hacia el Norte se consolida y crece. Los límites al interior del triángulo se diversifican y son todos ellos de carácter interno, además el río ya no es un límite que define el traspaso a zonas periféricas si no que ya ha quedado en una posición interna; entonces se puede afirmar que es durante la década de los sesenta cuando el sistema de periferias interiores de Lima comienza a formarse.

Entre los años 1972 y 1981 se aprecia la apertura del trazado de Lima hacia una nueva dirección: la Sierra central. Esta extensión de la ciudad tendrá como eje la carretera central acompañada del tren, dirección hacia donde los límites periféricos se extienden en estos planos.

A través del trabajo cartográfico presentado se llegó a definir el perímetro del área ocupada por el sistema de P.I., considerando la posición que tienen los límites periféricos al momento de quedar formado el sistema, es decir, a principios de la década de los ochenta (figura 5).

Con respecto a los focos de degradación hallados, ya se ha mencionado el cauce del río, al que desde la administración ciudadana se le considera un espacio residual que no debe mostrarse: su falta de apertura a la ciudad se refuerza con muros y un vallado casi continuo en las calles paralelas al río. Al cauce hay que agregar una serie de focos de degradación que van situándose adyacentes a consolidated thus continuing its expansion. The borders located within the triangle became diversified and all of them were already enclosed within the city. Likewise, the river was no longer the border that divided peripheral and central areas and also became part of the inner area of the metropolis. Therefore, it is possible to say that the 1960s marked the emergence of the system of inner peripheries of Lima.

Between 1972 and 1982 the city began to expand towards a new direction: the central Sierra. Such an expansion relied on the central highway and the railway system; the following maps show the extension of the new peripheral borders.

This cartographic exercise contributed to define the perimeter of the system of inner peripheries; such a goal was achieved through the identification of the position of peripheral borders once the system was finally completed at the beginning of the 1980s (see figure 5).

With respect to the focal points of degradation discovered is the importance of the Rimac River. This river has been regarded by the city administration as a residual space that should be kept hidden from view: such concealment is reinforced by the almost continuous walls and fences built on the streets that run parallel to the river. There is also a series of sources of 
él en su recorrido: industrias abandonadas, sitios eriazos y basurales.

Por otra parte, la topografía ha sido decisiva en la ubicación de las primeras barriadas periféricas en Lima. Ejemplo de esto son los asentamientos que surgieron durante los años cuarenta en los cerros San Cosme, El Pino y El Agustino. Todos ellos llegaron a poblarse con una densidad de viviendas alta, por el escaso terreno plano con el que contaban; esta situación fue generando barrios donde el espacio de la calle permite una mezcla entre lo privado y lo público, y donde según Aranda ${ }^{24}$ se dan nuevas formas de integración social.

\section{BARRIOS FOCOS DE VULNERABILIDAD}

La ubicación de los barrios analizados queda referida en el siguiente plano de Barrios Focos de Vulnerabilidad (figura 6). Estos barrios focos de vulnerabilidad corresponden a las antiguas barriadas de esta zona de Lima que desde sus orígenes hasta el presente han sufrido un doble proceso; por un lado, se han consolidado en tanto han obtenido los servicios básicos y en muchos casos, también la pavimentación e iluminación de sus calles, pero por otra parte, los problemas de vulnerabilidad que los caracterizaron desde sus inicios se mantienen o se han hecho más pregnantes, como la delincuencia

24 Aranda, 2007. degradation located along this course of water: abandoned industries, deserted lands and waste dumps.

On the other hand, topography has been a decisive factor in the location of the first peripheral slums that appeared in Lima. This is verified by the settlements established in the San Cosme, El Pino and El Agustino hills during the 1940s. The lack of flat terrain in these areas triggered a steep rise in housing density, thereby leading to the emergence of neighborhoods where the street is the space where private and public spheres converge; according toAranda ${ }^{24}$, such a concurrence generates new forms of social integration.

\section{NEIGHBORHOODS THAT ACT AS FOCAL POINTS OF VULNERABILITY}

The location of the analyzed neighborhoods is displayed on the map entitled neighborhoods that act as focal points of vulnerability (figure 6). These neighborhoods are old slums that, historically, have undergone a double process. On the one hand, they have become consolidated as they have been provided with basic services with most of them being surfaced with asphalt and provided with street lighting,but on the other hand, the vulnerability issues common to these

24 Aranda, 2007. 
FIGURA 6. PLANO DE RELACIONES ENTRE LOS BARRIOS FOCOS DE VULNERABILIDAD DEL SISTEMA DE PERIFERIAS INTERIORES

FIGURE 6.MAP DEPICTING THE RELATIONSHIPS AMONG THE NEIGHBORHOODS THAT ACT AS FOCAL POINTS OF VULNERABILITY WITHIN THE SYSTEM OF INNER PERIPHERIES

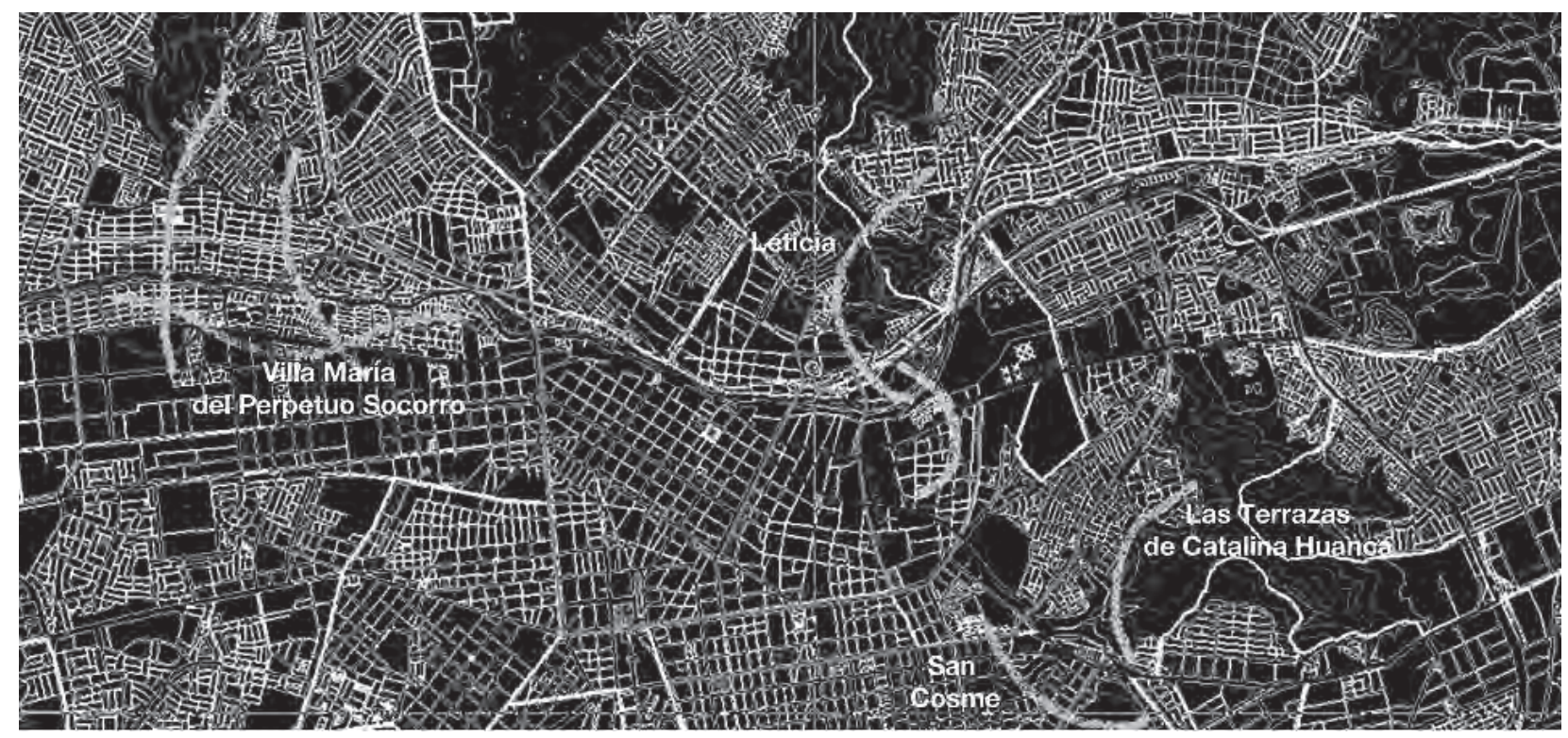

Fuente: Elaborado Paula Kapstein

Source: Elaborated by Paula Kapstein. 
y la falta de seguridad, el riesgo físico por un mal emplazamiento o la falta de accesibilidad.

Se considera como un barrio foco de vulnerabilidad a aquella barriada de más de cincuenta años de antigüedad, cuyo origen es informal, y que presenta carencias en sus aspectos de configuración física y urbana, todo lo cual incide en una baja calidad de vida, en la existencia de problemas sociales, en una pobreza endógena, en un entorno medioambientalmente contaminado y en la obsolescencia de las estructuras urbanas que contiene. Al mismo tiempo, por su propio desorden y fragmentación, estos barrios son capaces de incidir en la degradación de los otros barrios contenidos en el sistema de periferias interiores ${ }^{25}$. Es decir, los barrios focos de vulnerabilidad son aquellos que presentan la mayor degradación dentro del sistema de periferias interiores, el cual en total integra diez barrios vulnerables.

Los barrios identificados como focos de vulnerabilidad ubicados dentro del sistema de periferias interiores son: Villa María del Perpetuo Socorro (Cercado de Lima, zona de la MIRR), Leticia (Rímac), Las terrazas de Catalina Huanca (El Agustino) y San Cosme (La Victoria). A continuación, se presenta un breve análisis del último de ellos, San Cosme, que por su propia configuración geomorfológica se presenta como una Periferia Interior

25 Kapstein, 2010 areas such as crime, the lack of security and physical risk resulting from poorly developed infrastructure or the lack of accessibility have either persisted or even widened.

A neighborhood that act as focal points of vulnerability is considered as informal slum of more than fifty years old suffering from physical and urban deprivation. All these characteristics translate intoa low quality of life, the emergence of social problems, endogenous poverty, pollution and the lack of urban structures. At the same time, and due to their own disorganization and fragmentation, these neighborhoods may directly affect the degradation process of other slums located within the system of inner peripheries ${ }^{25}$. In other words, the neighborhoods that act as focal points of vulnerability are those slumswith the higher degradation level within the system of inner peripheries, which comprises ten vulnerable neighborhoods.

The neighborhoods that act as focal points of vulnerability identified within this system are: Villa Maria del Perpetuo Socorro (Cercado de Lima, MIRR area), Leticia (Rimac), Las Terrazas de Catalina Huanca (El Agustino) and San Cosme (La Victoria). Below is a brief summary of San Cosme, a neighborhood that, due to its own

25 Kapstein, 2010. 
contenida dentro de otra Periferia Interior de mayor tamaño.

El sistema de periferias interiores se compone de tres subsistemas, que pueden verse en el plano de la figura 6 de izquierda a derecha: el primero se forma por San Martín de Porres y Mirones, y el otro se compone de San Martín de Porres y Villa María; a continuación el siguiente subsistema se compone de parte de San Juan de Lurigancho, Leticia y Cantagallo y se relaciona con Barrios Altos, situado al otro lado del río Rímac; y el último de ellos se aleja del río y se compone de cuatro barriadas: Las Terrazas de Catalina Huanca, San Pedro de Ate, San Cosme y El Pino. Este último subsistema queda integrado por algunas avenidas que le dan continuidad: las avenidas México y Riva Agüero que recorren desde el centro de la ciudad hacia El Agustino y, por otro lado, la Vía del Evitamiento que permite la circulación vehicular por detrás del cerro y su enlace al resto de la ciudad. Este subsistema se sitúa en una posición periférica en el sistema de periferias interiores.

En el plano de la figura 6 se aprecian los barrios focos de vulnerabilidad. En la zona que va de la Av. Caquetá a Callao el barrio de mayor vulnerabilidad es Villa María del Perpetuo Socorro, en la zona central el barrio de mayor vulnerabilidad es Leticia, y en la zona de El Agustino hay dos focos de vulnerabilidad: Las Terrazas de Catalina Huanca y San Cosme. geomorphological configuration, emerges as an Inner Periphery contained within a larger Inner Periphery.

Figure 6 shows the system of inner peripheries composed of three subsystems: the first comprises of San Martin de Porres and Mirones and the other comprises of San Martin de Porres and Villa Maria; the second subsystem is composed of parts of San Juan de Lurigancho, Leticia and Cantagallo - and maintains a relationship with Barrios Altos, located on the other side of the Rimac River; and the third is located away from the river and comprises of four slums: Las Terrazas de Catalina Huanca, San Pedro de Ate, San Cosme and El Pino. The latter subsystem has some integrated streets that ensure its continuity: the Mexico and Riva Agüero avenues that extend from the downtown of the city to El Agustino, and the Via del Evitamiento, which runs from behind the hill to the rest of the city. This subsystem is located in a peripheral position within the system of inner peripheries.

Map 6 also shows the neighborhoods that act as focal points of vulnerability. The first, Villa Maria del Perpetuo Socorro, is located in the area comprising Caqueta Avenue and Callao; the second vulnerable neighborhood, Leticia, is located in the central zone; lastly, the zone of El 


\section{SAN COSME (LA VICTORIA)}

El análisis de San Cosme se realizó primeramente a través de un estudio de la bibliografía existente sobre su origen y formación para, a continuación, abordar un trabajo de campo en la zona que consideró desde entrevistas con los vecinos, llevadas a cabo con el fin de conocer sus necesidades y las debilidades del barrio, y distintos recorridos a pie por el cerro junto a personal de la Subgerencia de Promoción Social de la Municipalidad de La Victoria, realizados en el mes de mayo de $2013^{26}$.

La barriada San Cosme es fácilmente identificable pues ocupa todo el cerro conocido con el mismo nombre, situado frente a otro cerro poblado por invasiones dadas en la década de los cincuenta, El Pino. El origen de San Cosme se remonta al año 1946 y está relacionado con un movimiento urbano popular que tomó notoriedad en el contexto de la efervescencia política generada por el triunfo del Frente Democrático Nacional según comenta Matos Mar $^{27}$. Entonces, el cerro San Cosme pertenecía a los hermanos Cánepa que eran también propietarios de la hacienda "El Pino". En el año 1946 se produjo el traslado de los mercados mayorista y minorista del barrio de Manzanilla a su actual ubicación en La Victoria, al lado de San Cosme, siendo esto el hecho detonante de la llegada

26 Nuestros agradecimientos a Evelyn Orcón y a Wendy Ventura de la Municipalidad de La Victoria por gestionar nuestras visitas. 27 Matos Mar, 1977
Agustino contains two focus of vulnerability: Las Terrazas de Catalina Huanca and San Cosme.

\section{SAN COSME (LA VICTORIA)}

The analysis of the neighborhood of San Cosme was conducted through a literature review regarding its origin and emergence. There followed field visits and interviews with local leaders conducted in order to identify the needs and weaknesses of this neighborhood.This phase also included guided walks with staff from the Division for Social Promotion at the Municipality of La Victoria, which took place in May, $2013^{26}$.

The slum of San Cosme can be easily identified as it covers the hill that bears the same name, which is located in front of another hill El Pino that was inhabited after successive settlements that occurred during the 1950s. As Matos Mar suggests ${ }^{27}$, the origin of San Cosme dates back to 1946 and is related to a popular urban movement that became notorious within the context of the political volatility sparked by the triumph of the National Democratic Party. Back then the San Cosme hill was in the hands of the Canepa brothers, who also owned the farm "El Pino".

26 We are grateful to Evelyn Orcon and Wendy Ventura, from the Municipality of La Victoria, for coordinating our visits.

27 Matos Mar, 1977. 
de los comerciantes y trabajadores de dichos mercados a instalarse en los alrededores de su fuente de trabajo.

Según Matos Mar $^{28}$ en julio de 1946 un grupo de trabajadores del mercado mayorista (junto a algunos migrantes serranos) se instaló al costado de la Av. San Pablo, al pie del cerro San Cosme. El 1 de septiembre los vecinos acordaron tomar el cerro, aunque esta invasión no se concretó ya que no contó con el apoyo de todos los pobladores y el 24 de septiembre de 1946 se llevó a cabo la primera invasión organizada, en la cual participaron unas ciento veinte personas que subieron al cerro para colocar las primeras viviendas. A partir de esta invasión, los vecinos formaron la "Asociación de Pobladores del Cerro San Cosme", que perdura hasta el día de hoy, según Víctor Calderón, dirigente de San Cosme ${ }^{29}$.

El movimiento vecinal fue tan potente que consiguieron lo que muchas otras barriadas tardaron años en lograr: el apoyo del Estado. Dicha colaboración permitió, entre otras cosas, que San Cosme se fuera consolidando como barrio y creciendo en densidad poblacional al seguir recibiendo migrantes serranos o vecinos de otras partes de Lima durante las siguientes décadas.

\footnotetext{
28 Ibíd

29 En conversación durante la visita al cerro San Cosme, el día 7 de mayo de 2013
}

In 1946 the wholesale and retail trade activity carried out in the neighborhood of Manzanilla was transferred to its current location in La Victoria, next to San Cosme. This event led to the arrival of merchants and workers into the areas surrounding their source of employment.

As Matos Mar ${ }^{28}$ points out, on July 1946 a group of people working in the wholesale area (including some immigrants from the Sierra) settled along the San Pablo Avenue at the foothills of San Cosme. In September that year a group of neighbors agreed to settle the hill. However such an action was not completed due to a lack of support by the rest of settlers. Then, on September 241946 the first organized invasion was carried out by approximately 120 individuals who climbed the hill to build the first dwellings. According to Victor Calderon, the local leader of San Cosme $e^{29}$, thissettlement marked the birth of the "Association of Residents of San Cosme", an entity that still exists today.

This neighborhood movement was so powerful that it in achieving what other slums could not: the support of the State.This cooperation effort enabled the consolidation of San Cosme, which

\footnotetext{
28 Ibíd.

29 Declarations made during a visit to San Cosme on May 7, 2013.
} 
En 1957, año en que Matos Mar realiza su censo de barriadas en Lima, el cerro San Cosme tenía una población de 5.674 personas. En 2007 contaba con 19.744 personas censadas (INEI, 2007). Estas cifras permiten observar que la población se ha multiplicado por 3,47 (lo que representa un aumento del 248\%), mientras que en 1961 la metrópoli de Lima tenía 1.957.267 habitantes según el censo del Instituto Nacional de Estadísticas de ese año y en el año 2007 tenía 9.152.700 habitantes, habiéndose multiplicado su población por 4,68. Es decir su aumento fue de un 368\% entre 1961 y 2007.

El aumento de la metrópoli es vertiginoso pero, sin duda, el crecimiento poblacional de San Cosme también lo es; aún sin alcanzar las tasas de crecimiento de la metrópoli, en dicho cerro se ha logrado colmatar la superficie existente, creándose una Periferia Interior con una densidad más alta que la de los barrios de su alrededor. Esta observación permite verificar una de nuestras hipótesis, la que alude a que las tasas de crecimiento poblacional de los barrios focos de vulnerabilidad pueden reflejar la media de crecimiento de la metrópoli durante el periodo observado.

Tal como puede apreciarse en la foto aérea de la figura 7, el cerro tiene una forma curva, ligeramente alargada, presentando una concavidad hacia el sur. Al recorrer la zona se hace patente como esta curvatura permite ir teniendo diversas vistas tanto would lead to an increase in population density as the result of migrations from the Sierra and other parts of Lima over the following decades.

In 1957, the same year in which Matos Mar conducted the census of slums in Lima, San Cosme had a population of 5,674 inhabitants. In 2007, the number of inhabitants in this neighborhood rose to 19,744 (INEI, 2007). These figures show that the population in this area grew by 3.47 times (an increase of 248 percent); in the case of Lima, while the 1961 census conducted by the National Statistical Institute gave a total population of 1,957,267 inhabitants, the 2007 census revealed a total population of 9,152,700 inhabitants which grew by 4,68 times. In other words, there was an increase of 368 percent during the period spanning 1961 to 2007.

The metropolis has grown at a dizzying pace. However, San Cosme has also experienced a steep population increase. Though it has not reached the growth rates of the metropolis, San Cosme has completely covered the available surface, thus giving rise to an Inner Periphery that has a higher density when compared to the surrounding neighborhoods. This observation confirms one of our hypotheses: the population growth rates of neighborhoods that act as focal points of 
de las laderas del mismo cerro, como de El Pino o, a lo lejos, de la zona de San Pedro de Ate.

San Cosme es más pequeño que El Pino tanto en sus medidas en planta ${ }^{30}$ como en cuanto a su altura. En San Cosme no hay calles vehiculares, sólo hay pasajes y escaleras, como puede apreciarse en la foto aérea de la figura 7 y en las fotos de la figura 8; en estas imágenes se percibe también la alta densidad edificatoria del cerro, la cual es de aproximadamente 320 viviendas/ha $\mathrm{a}^{31}$, lo que tiene más desventajas que ventajas. Se puede considerar como una ventaja la cohesión social de los vecinos que se produce por la cercanía de sus viviendas (aunque esto, ciertamente, es relativo) y, como una desventaja, se puede tomar en cuenta el hacinamiento y la presencia de enfermedades contagiosas como la tuberculosis (TBC). Otra de sus desventajas queda relacionada con las bajas condiciones de las viviendas, las cuales tienen un alto porcentaje de tugurización: en una misma vivienda pueden convivir varias familias en reducidos espacios. Lo cual conduce a las personas a vivir en pésimas condiciones y en promiscuidad. En relación al barrio, hay escasos espacios de encuentro, salvo una

30 En planta el cerro San Cosme cuenta con 7,5 ha (superficie medida sobre el plano de 2012 de Lima. Fuente: Instituto Geográfico Nacional).

31 Densidad calculada sobre la foto aérea de la figura 7 de abril de 2013. La densidad no siempre ha sido tan alta, ha aumentado según ha ido creciendo la población del cerro y las viviendas han ocupado toda la superficie disponible en el terreno, quedándose sin patios. vulnerability may reflect the average growth of the metropolis during the period analyzed.

As figure 7 suggests, San Cosme has a curved and slightly elongated shape with a southward concavity. Walking through the area, it is possible to see how this curvature allowsthe observation of the slopes of this hill and that of El Pino, and even distinguish the zone of San Pedro de Ate from far away.

San Cosme is smaller than El Pino in terms of surface $^{30}$ and height. San Cosme lacks vehicular roadways; there are only passageways and stairways as can be seen in the aerial photograph figure 7 . These images also reveal the high housing density of the area, which is of approximately 320 dwellings/ ha ${ }^{31}$; such a configuration brings more disadvantages than advantages. One of the positive aspects offered by this unit is the social cohesion among neighbors which is generated as the result of the closeness of their dwellings to each other (though this is certainly relative); as for the disadvantages of this area, overcrowding

30 San Cosme has a surface of 7.5 ha measured according to the map of Lima for the year 2012. Source: National Geographic Institute

31 Density estimated according to the aerial picture (figure 7) taken on April, 2013. Such a density has not always been that high; it increased according to population growth. Dwellings have covered the whole surface of the hill, thus leaving no space for courtyards.

revista invi No 82 / November 2014 / Volume № 29: 19-62 
FIGURA 7. FOTO AÉREA DE SAN COSME FIGURE 7. AERIAL PICTURE OF SAN COSME

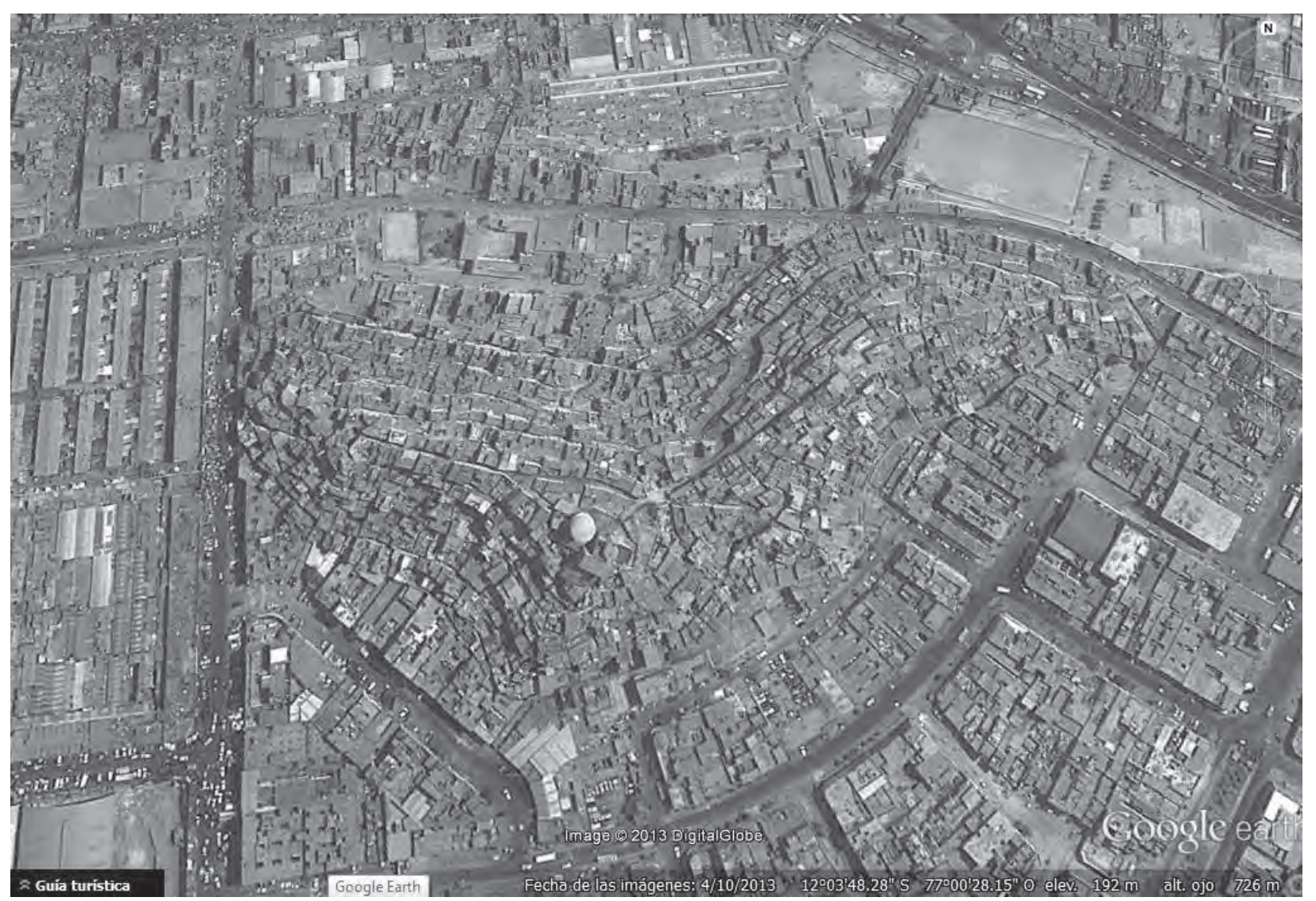

Fuente: Google Earth, abril de 2013

Source: Google Earth, April, 2013. 
FIGURA 8. FOTOS DEL ESPACIO PÚBLICO EN SAN COSME; SU USO ES INTENSO, YA QUE LOS LOTES NO CUENTAN CON PATIOS

FIGURE 8. PICTURES OF PUBLIC SPACES IN SAN COSME; THESE AREAS ARE HEAVILY USED DUE TO THE LACK OF COURTYARDS
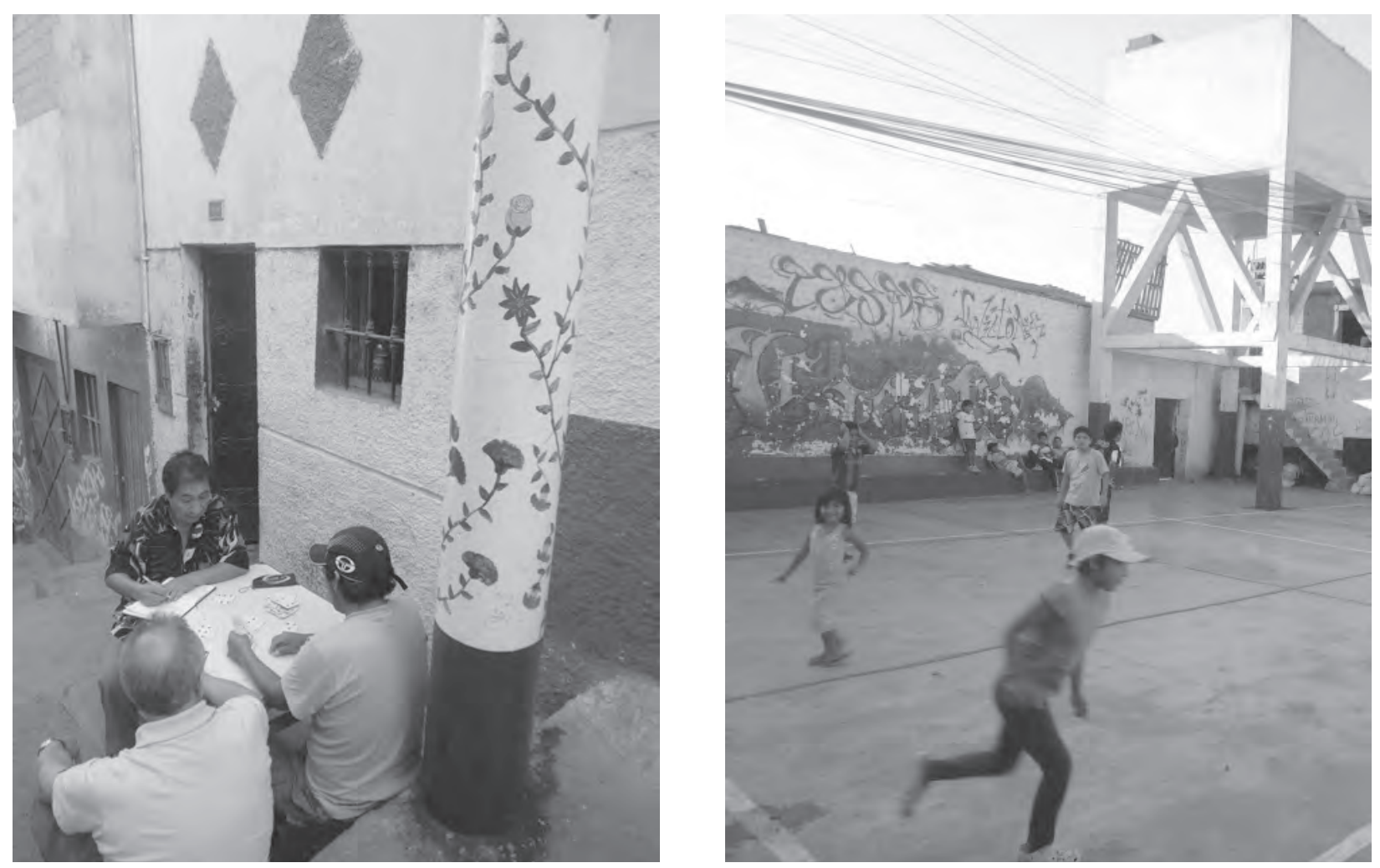

Fotos: Paula Kapstein, mayo de 2013.

Source: Photo by Paula Kapstein, May 2013. 
pequeña plaza con una cancha de fútbol pavimentada en la zona más alta del cerro.

Según planteó Matos Mar en su libro sobre las barriadas limeñas en 1957 y corroboró más tarde Driant en su estudio del año 1991, San Cosme se considera como la primera barriada de Lima porque representó un nuevo modelo de crecimiento urbano. San Cosme define el tipo barriada, pues cuenta desde su origen hasta hoy con los elementos que definen la condición de estos barrios: organización vecinal, ocupación progresiva del terreno dada por invasiones y emprendimiento económico.

El cerro San Cosme se sitúa en una posición retrasada con respecto al río Rímac, pero no por ello su presencia es menos relevante dentro del sistema de periferias interiores de Lima. Su importancia proviene de dos factores: su origen dado por la organización de sus pobladores y la delimitación de la barriada, aportada por la propia topografía del cerro, lo que le ha permitido configurarse como una entidad aparte, como si de una isla urbana se tratase. Esto permite afirmar que se trata de una Periferia Interior en sí misma, contenida en el sistema de periferias interiores general. Este rasgo puede apreciarse en la figura 7.

En cuanto a su vulnerabilidad, San Cosme presenta sobre todo problemas de carácter social: and the presence of contagious diseases such as tuberculosis (TB) emerge as problematic issues. Another disadvantage is represented by the low standards of dwellings, which can potentially become slums - different families living in the same dwelling. This situation leads to poor quality of life and promiscuity. As for the neighborhood, apart from a little square with a surfaced soccer pitch located at the top of the hill, there are few meeting spaces (figures 7 and 8).

As Matos Mar suggests in his book about the slums of Lima (1957) - verified by Driant in 1991-, San Cosme is regarded as the first shanty town that emerged in the city as it represented a new model of urban growth. San Cosmedescribes the slum type as it is composed of elements that define the condition of these spaces: neighborhood organization, progressive occupation of land as the result of invasions and entrepreneurship.

Despite being located behind the Rimac River, San Cosme plays an important role within the system of inner peripheries of Lima. Such a role is defined by two factors: its establishment -derived from the organized action of its residents - and the demarcation of the slum generated by the topography of the hill. These characteristics enabled this neighborhood to evolve as an independent unit, as though it were 
delincuencia juvenil y drogadicción y, con respecto a la salud, la presencia de la tuberculosis es alta ${ }^{32}$.

Con respecto a la situación medioambiental, la falta de higiene de las calles que rodean los mercados mayorista y minorista de La Parada es grande y lo mismo pasa en las calles que dan acceso al cerro San Cosme. Esta situación agrava los otros problemas enunciados; sin embargo, en el interior del cerro ha podido constatarse que las calles están limpias. Además, actualmente se están llevando a cabo por el Municipio algunas acciones de saneamiento e higiene de los espacios públicos, como el programa "Encala tu calle", destinado a limpiar y encalar las paredes exteriores de las viviendas ${ }^{33}$.

Por otro lado, acerca del estado de las viviendas, hay varias que presentan riesgo de derrumbe o deslizamientos por el mal estado de sus paredes y de los muros de contención, ya que estos últimos están construidos con materiales deleznables dispuestos sin las técnicas apropiadas.

San Cosme se sitúa como un núcleo que articula otros barrios vulnerables, formando parte de un subsistema que reúne los siguientes barrios

32 Según el Dr. E. Romualdo, jefe médico del centro de salud de San Cosme, su incidencia es de 1.033 enfermos por cada 100.000 habitantes (estas cifras representan un $1 \%$ ).

33 Este programa se lleva a cabo por la Municipalidad de La Victoria con financiamiento belga y cuenta con una alta participación vecinal. La cal absorbe bacterias y gérmenes de las paredes. an urban island. Therefore, it is possible to refer to this area as an Inner Periphery contained within the general system of inner peripheries. Such a feature can be seen in figure 7 .

As for vulnerability, San Cosme is mainly affected by social problems: juvenile delinquency and drug abuse. With respect to health, there is a high incidence of tuberculosis ${ }^{32}$.

In environmental terms, the streets surrounding the wholesale and retail markets of La Parada and the access to San Cosme are affected by hygiene issues. This situation exacerbates the abovementioned problems; however, the streets located within the hill are kept clean. Likewise, the Municipality has been conducting some sanitation and hygiene campaigns in public spaces; this is the case of the "Whitewash your Street" program, which is intended to clean and whitewash the external walls of dwellings. ${ }^{33}$

On the other hand, an important number of dwellings are at risk of collapse or slipping due to the poor condition of walls and retaining

32 According to Dr. E. Romualdo, chief medical officer at the health center of San Cosme, there are 1,033 cases of TB per 100,000 inhabitants (these figures represent a 1 percent).

33 A popular Belgian-funded program conducted by the Municipality of La Victoria. Lime absorbs bacteria and germs from walls. 
vulnerables: Las Terrazas de Catalina Huanca, San Pedro de Ate y El Pino.

El caso de San Cosme se presenta como un caso paradigmático ya que las variables que le aportan vulnerabilidad, se pueden encontrar en los otros barrios focos de vulnerabilidad del sistema de periferias interiores.

\section{Conclusiones}

\section{LA SUPERACIÓN DE LOS PROBLEMAS DE VULNERABILIDAD}

La identificación y posterior delimitación de las zonas donde se localizan los problemas urbanos, físicos y sociales que determinan situaciones de vulnerabilidad urbana en el centro de Lima podría constituir el paso previo para definir una herramienta que, aplicada al planeamiento de Lima, permita llevar a cabo prácticas que posibiliten la superación de la vulnerabilidad urbana. Pero, ¿cómo puede darse esto en una ciudad con un área metropolitana compuesta de 49 distritos?, y ¿cómo se pueden abordar los problemas de una zona extensa de Lima como es el sistema de periferias interiores que integra parcialmente nueve distritos?

La superación de los problemas del sistema de periferias interiores se entiende relacionada con una walls, which are poorly constructed from cheap materials.

This neighborhood emerges as the hub that connects other vulnerable neighborhoods: Las Terrazas de Catalina Huanca, San Pedro de Ate and El Pino.

San Cosme is a paradigmatic case as its vulnerability-generating variables can be found in other vulnerability-generating neighborhoods within the system of inner peripheries.

\section{Conclusions}

\section{OVERCOMING VULNERABILITY ISSUES}

Demarcating and identifying the areas of downtown Lima that concentrate urban, physical and social problems may contribute to address urban vulnerability. The problem is that Lima has a metropolitan area composed of 49 districts and downtown Lima is composed of 9 districts. What can be done to solve this issue?

Overcoming the problems associated with the system of inner peripheries implies an improvement in urban terms. As Roch ${ }^{34}$ points

34 Roch, 2007. 
mejora de lo urbano. Tal como apunta Roch ${ }^{34}$, la ciudad por su misma condición urbana puede atenuar los problemas de vulnerabilidad social. Esta observación se refiere al hecho de que en las áreas céntricas suele haber una red de equipamientos y una mejor accesibilidad a los distintos servicios que pueden facilitar la vida a las personas que viven en situación de vulnerabilidad y/o de marginalidad.

La anterior observación nos permite incidir en la importancia que podría tener para la regeneración de los barrios situados en la zona delimitada el contar con una red de equipamientos jerarquizada de acuerdo a la escala y al tamaño del sistema de periferias interiores. Esto debe regularse desde el planeamiento, por lo que resulta urgente generar un instrumento supramunicipal que sea vinculante para el resto de planes urbanos generados por los distintos municipios integrados en la zona. Actualmente hay una falta de coordinación entre los distintos niveles de la administración ciudadana ${ }^{35}$, lo que se traduce en la ausencia de actuaciones conjuntas de dos o más municipalidades distritales.

A pesar de lo anterior, no podemos dejar de observar la variedad de actores que están haciendo frente

34 Roch, 2007

35 Falta transversalidad tanto en la configuración de las políticas de desarrollo urbano de la ciudad como en la implantación de los programas de mejora urbana y social de los distritos. Pero, probablemente, esta transversalidad no podrá concretarse sin que antes se den importantes pasos para lograr descentralizar los poderes políticos. out, the city, due to its urban condition, can tackle social vulnerability problems. Such an observation is related to the fact that downtown areas tend to have a network of amenities and a better access to the different services that may facilitate the lives of those living in vulnerable and marginal conditions.

Within the context of the regeneration of the neighborhoods located in the demarcated area, the abovementioned observation allows us to address the importance of having a network of amenities especially designed for the system of inner peripheries. This should be regulated during the planning stage. Thereforethere is an urgent need to create a supra-municipal instrument intended to bind the rest of urban plans elaborated by the different municipalities within the area. Currently there is no coordination at city administration level ${ }^{35}$ and this translates into a lack of joint initiatives conducted by two or more municipalities.

Despite the above, we cannot refrain from observing the different actors that are tackling

35 There is a lack of a multidimensional approach in the elaboration of urban development policies and in the implementation of urban and social improvement programs. However, such an approach may only be realized so long as important measures aimed at decentralizing political forces are implemented. 
a los problemas relacionados con la vulnerabilidad urbana en Lima: asociaciones vecinales, instituciones de la administración ciudadana, colectivos dedicados a la investigación urbana (que acogen estudiantes y profesores de diversas universidades), organismos de cooperación internacionales y algunas entidades privadas. Sin embargo, nuevamente se presenta entre ellos una falta de encuentro o de conexión que, de existir, podría mejorar notablemente la eficacia de sus actuaciones.

Construir una estrategia de regeneración urbana permitiría aunar los esfuerzos que ya se están llevando a cabo puntualmente por la sociedad civil y por diversas entidades, además de encontrar una metodología de trabajo participativo que atienda jerárquicamente los diversos problemas que se presentan con una perspectiva de largo alcance. Tal como comenta Carter ${ }^{36}$ el éxito de la regeneración urbana radica en contar con una estrategia local, de carácter multisectorial y capaz de actuar a través de la asociación de diversos agentes. En lo que respecta a este trabajo se persigue proponer una estrategia general de regeneración urbana que sea efectiva en la superación de los problemas detectados.

La estrategia de regeneración surge de la verificación de las hipótesis previamente planteadas y de

36 Carter, 2000 the issues related to urban vulnerability in Lima, neighborhood associations, institutions related to city administration, collective groups engaged in urban research (composed of students and professors from different universities), organisms for international cooperation and some private entities. However, there is again a lack of connection which if implemented would dramatically improve the efficiency of these initiatives.

The elaboration of an urban regeneration strategy would enable cooperation among efforts that are already in place by the civil society and different entities; likewise, it would also be possible to find a participative methodology aimed at addressing different hierarchically arranged issues on a long-term basis. As Carter ${ }^{36}$ suggests, the success of urban regeneration lies in having a local, multisectoral strategy capable of operating through the association of different agents. As for this paper, the goal is to propose an effective general strategy on urban regeneration aimed at overcoming the abovementioned problems.

This regeneration strategy emerged as the result of the verification of the hypotheses proposed by this paper and the needs of neighbors, which were identified over the course of different workshops.

36 Carter, 2000 
las necesidades de los vecinos conocidas a través de los talleres realizados.

\section{VERIFICACIÓN DE HIPÓTESIS}

La primera de la hipótesis hacía alusión al tamaño del sistema de periferias interiores y a su complejidad. Se pudo comprobar que la zona delimitada se compone de barrios que tienen problemas de mayor vulnerabilidad y de barrios menos vulnerables; y que tampoco hay una homogeneidad en cuanto al tipo de problemas hallados ni a su origen. Sin embargo, los barrios que integran el sistema se relacionan por la continuidad existente entre ellos, dada principalmente por los mismos límites que definen el área total del sistema y al mismo tiempo la diferencian, como el río Rímac y algunas avenidas.

En cuanto a la hipótesis que aludía a que el sistema de periferias interiores constituye el soporte que sustenta el traslado de lo rural a lo urbano, esta también ha podido comprobarse. El origen de las familias determina su actividad laboral casi siempre, y con ella el tipo de ocupación que se hace del espacio público.

Por otra parte, el hecho de que la densidad edificatoria es mayor en los barrios focos de vulnerabilidad que en el resto de la ciudad, también ha podido comprobarse y tiene que ver con su antigüedad y la rapidez de su crecimiento poblacional.

\section{VERIFICATION OF HYPOTHESES}

The first hypothesis alluded to the size and complexity of the system of inner peripheries. This paper verified that the demarcated area comprises neighborhoods with major vulnerability issues and less vulnerable neighborhoods. It was also confirmed that there was no homogeneity regarding the nature and origin of identified problems. However, the neighborhoods belonging to this system are related to each other thanks to the continuity that exists among them, which is defined by the same borders that demarcate and differentiate the total area of the system: the Rimac River and some roadways.

The second hypothesis, which discussed the key role of the system of inner peripheries when moving from the urban to the rural sphere, was also verified. Most of the time, the origin of families defines their economic activity and the type of use given to the public space.

On the other hand, it was also confirmed the fact that housing density is greater in vulnerabilitygenerating neighborhoods than in the rest of the city. This circumstance has to do with the age of neighborhoods and the speed of population growth.

Finally, the needs of the neighborhoods analyzed are always related to urgent issues: lack of hygiene 
Finalmente, las necesidades de los barrios analizados aluden siempre a cuestiones perentorias: falta de higiene y de seguridad en las calles, falta de servicios básicos y de acceso a la salud, falta de educación en los niños y jóvenes, graves problemas de drogas o alcoholismo que conducen a la delincuencia, y la persistencia entre la población de enfermedades graves. Todos estos problemas se agravan por la limitación urbana que presentan los barrios: quedan separados de la ciudad por verdaderas barreras (el río, infraestructuras de tráfico, muros o rejas, etc.) y por una falta de estudio y consideración en la regulación urbana y el planeamiento, todo lo cual dificulta su integración y su articulación.

\section{ESTRATEGIAS DE REGENERACIÓN}

Cualquier estrategia de recuperación de periferias interiores requiere de un conocimiento detallado de los barrios y de sus problemas, es por ello que este trabajo persiguió primero definir un estado de la cuestión lo más exhaustivo posible y, segundo, la realización de un trabajo de campo con las comunidades de vecinos implicadas. Todo ello, finalmente, permitió desarrollar una metodología de análisis de la vulnerabilidad de barrios que consideró problemas urbanos, físicos y sociales.

El fin de la evaluación de la vulnerabilidad de los barrios incluidos en el sistema de periferias interiores es propiciar el sustrato analítico para la and security on the streets, lack of basic services and access to health care, lack of education among children and youth, severe drug abuse and alcoholism leading to the perpetration of crimes and a high incidence of serious diseases. All these problems are exacerbated by the urban limitation of these neighborhoods: they are separated from the city by real barriers (the river, road infrastructures, walls, fences, etc.) and the lack of studies and awareness on urban regulation and urban planning, thereby hindering their integration and connection to other areas.

\section{REGENERATION STRATEGIES}

Any strategy aimed at recovering the inner peripheries requires a thorough knowledge of neighborhoods and their problems. This is why this paper defined the current status of this issue to the best extent possible and conducted field visits to relevant neighbor communities. This allowed the development of a methodology for analyzing the vulnerability of neighborhoods that included urban, physical and social problems.

The goal of the vulnerability assessment of neighborhoods located within the system of inner peripheries is to provide the analytical bases for the development of a Master Plan on 
formalización de un Plan Director para la Regeneración de las Periferias Interiores de Lima. Este Plan podría ser capaz de establecer unos consensos de actuaciones minimas capaces de articular intervenciones urbanas de mejora básicas para todos los barrios, enmarcadas en una jerarquía. Esto último resulta de extrema importancia porque sin un orden justificado por la necesidad, que permita dar prioridad a la resolución de problemas, la regeneración de áreas urbanas podría resultar inabordable o dilatarse en el tiempo sin conseguir resultados.

El Plan Director de Regeneración de Periferias Interiores puede ser de utilidad para ordenar la intervención de equipos multidisciplinares y de diversas entidades. Además de permitir la cooperación entre las distintas municipalidades distritales y administraciones públicas implicadas en la zona.

\section{Bibliografía}

ARANDA DIOSES, Edith. Las cambiantes formas de sociabilidad y de construcción de identidades en Lima metropolitana. [En línea]. Debates en Sociologia. (32): 109-123, 2007. ISSN 0254-9220. Disponible en: http://revistas.pucp.edu.pe/index.php/ debatesensociologia/article/view/2562

CARTER, Andrew. Strategy and partnership in urban regeneration. En: ROBERTS, Peter, ed. y SYKES, Hugh, ed. Urban regeneration. Londres, Sage. 2000.

ARTÍCULO: Las periferias interiores de Lima: localización e identificación de los barrios focos de vulnerabilidad. El caso de San Cosme / Paula Kapstein López, Edith Aranda Dioses the Regeneration of the Inner Peripheries of Lima. This Plan would eventually establish a consensus on minimum participation capable of relating basic urban interventions within a hierarchical system. The latter is extremely important as the lack of a justified order intended to prioritize the resolution of problems may result either in the incapacity to address the regeneration of urban areas or the adoption of late and futile responses.

The Master Plan on the Regeneration of Inner Peripheries can be useful when organizing interventions conducted by multidisciplinary teams from different entities. Likewise, it would enable cooperation among the different municipalities and public administrations involved.

DRIANT, Jean-Claude. Las barriadas de Lima. Historia e interpretación. Lima, IFEA, DESCO. 1991. ISBN 84-89302-09-X

GONZALES DE OLARTE, Efraín. La economía regional de Lima. Crecimiento, urbanización y clases populares. Lima, Instituto de Estudios Peruanos. 1992.

GÜNTHER DOERING, Juan. Planos de Lima 1613-1983. Municipalidad de Lima Metropolitana y Petro Perú, 1983.

revista invi № 82 / November 2014 / Volume Nº 29: 19-62 
HANNERZ, UIf. Exploración de la ciudad. Madrid, Fondo de Cultura Económica. 1993.

INSTITUTO Geográfico Nacional. Plano de Lima de 2012

INEI Instituto Nacional de Estadísticas e Informática del Perú. Censo del año 2007, Compendio estadístico año 2008 en www.inei.gob.pe y cartografía digital específica adquirida en Lima, 2013.

KAPSTEIN LÓPEZ; Paula. Vulnerabilidad y periferia interior. Ci[ur] Cuadernos de investigación urbanística. (71), julio 2010. Disponible en: http:// www2.aq.upm.es/Departamentos/Urbanismo/ institucional/numeros-ciur/ciur-71/

La periferia interior: un problema de vulnerabilidad no resuelto por el planeamiento urbano en Chile. España, Universidad Politécnica de Madrid. 2009. Tesis doctoral dirigida por Agustín Hernández Aja y leída en el Departamento de Urbanística y Ordenación del Territorio de la ETSA de Madrid.

MATOS MAR, José. Perú: Estado desbordado y sociedad nacional emergente. Lima, Editorial Universitaria de la Universidad Ricardo Palma. 2012. ISBN 978-612-4059-54-4

- Desborde popular y crisis del estado veinte años después. Lima, Fondo Editorial del Congreso del Perú. 2010. ISBN 9972-890-62-7

Las barriadas de Lima, 1957. Lima, Instituto de Estudios Peruano. 1977.
OFICINA Nacional de Planeamiento y Urbanismo del Perú. Plan Piloto de Lima, año 1949. Lima, Oficina Nacional de Planeamiento y Urbanismo.

RIOFRío BENAVIDES, Gustavo. Producir la ciudad (popular) de los 90. Entre el mercado y el Estado. Lima, DESCO. 1991.

ROCH PEÑA, Fernando. La ciudad histórica como lugar para la convivencia. Inmigración y vida urbana en el barrio de Lavapiés de Madrid. Madrid, Departamento de Urbanística y Ordenación del Territorio de la ETSAM. 2007.

SIPIÓN, Luis et al. Tendencias de crecimiento urbano de Lima metropolitana al año 2015. Lima, INEI, INADUR.1995. 